\title{
Rare Earth Metal Complexes of Bidentate Nitroxide Ligands: Synthesis and Electrochemistry
}

\author{
Jee Eon Kim, Justin A. Bogart, Patrick J. Carroll and Eric J. Schelter* \\ P. Roy and Diana T. Vagelos Laboratories, Department of Chemistry, University of Pennsylvania, \\ Philadelphia, PA 19104 \\ E-mail: schelter@sas.upenn.edu
}

\section{Supporting Information}

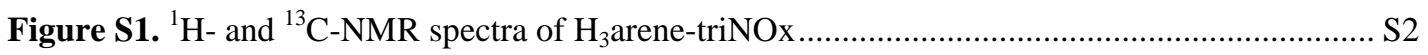

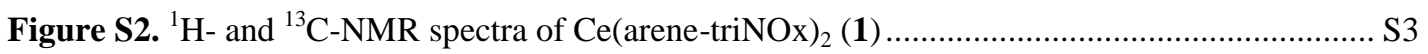

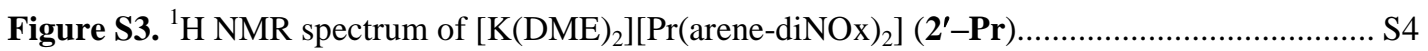

Figure S4. ${ }^{1} \mathrm{H}$ NMR spectrum of $\left[(\mathrm{py})_{2} \mathrm{~K}(18 \text {-crown-6)][Pr(arene-diNOx })_{2}\right](2-\mathrm{Pr})$....................... S5

Figure S5. ${ }^{1} \mathrm{H}$ NMR spectrum of $\left[(\mathrm{py})_{2} \mathrm{~K}(18 \text {-crown-6)][Tb(arene-diNOx })_{2}\right](\mathbf{2}-\mathbf{T b})$....................... S6

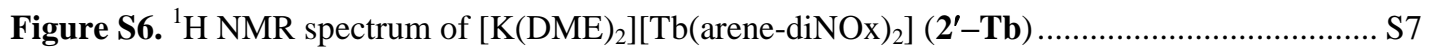

Figure S7. ${ }^{1} \mathrm{H}$ - and ${ }^{13} \mathrm{C}-\mathrm{NMR}$ spectra of $\left[(\mathrm{py})_{2} \mathrm{~K}(18 \text {-crown-6)][Y(arene-diNOx })_{2}\right](\mathbf{2}-\mathbf{Y})$............... S8

Figure S8. ${ }^{1} \mathrm{H}$ - and ${ }^{13} \mathrm{C}-\mathrm{NMR}$ spectra of $\left[\mathrm{K}(\mathrm{DME})_{2}\right]\left[\mathrm{Y}(\text { arene-diNOx })_{2}\right]\left(\mathbf{2}^{\prime}-\mathbf{Y}\right)$.............................. S9

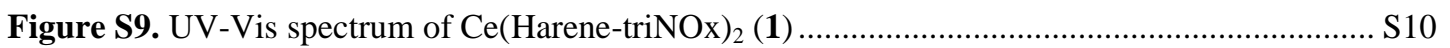

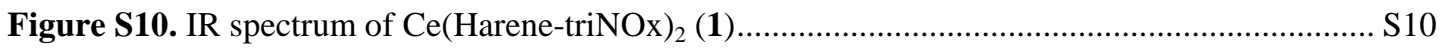

Figure S11. Cyclic Voltammograms of $\mathrm{H}_{3}$ arene-triNOx ................................................................. S11-

S12

Figure S12. Cyclic Voltammograms of Ce(Harene-triNOx $)_{2}(\mathbf{1})$ S13-

S14

Figure S13. Cyclic Voltammograms of $\left[(\mathrm{py})_{2} \mathrm{~K}(18 \text {-crown-6)][Pr(arene-diNOx })_{2}\right](2-\mathrm{Pr})$............... S15

Figure S14. Cyclic Voltammograms of [(py $\left.)_{2} \mathrm{~K}(18 \text {-crown-6)][Tb(arene-diNOx })_{2}\right]$ (2-Tb) ............. S16

Figure S15. Cyclic Voltammograms of $\left[(\mathrm{py})_{2} \mathrm{~K}(18 \text {-crown-6)][Y(arene-diNOx })_{2}\right](\mathbf{2}-\mathbf{Y})$................. S17

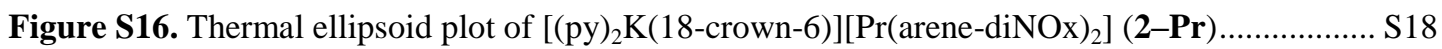

Figure S17. Thermal ellipsoid plot of $\left[(\mathrm{py})_{2} \mathrm{~K}(18 \text {-crown-6)][Tb(arene-diNOx })_{2}\right](\mathbf{2}-\mathbf{T b})$................ S18

Figure S18. UV-Vis spectrum of Ce(arene-diNOx $)_{2},\left[(\mathrm{py})_{2} \mathrm{~K}(18 \text {-crown-6)][Ln(arene-diNOx })_{2}\right](2-\mathbf{L n}, \mathrm{Ln}$

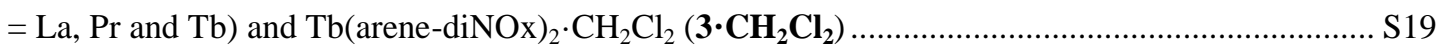

Figure S19. Plot of magnetization versus field of $\left[(\mathrm{py})_{2} \mathrm{~K}(18 \text {-crown-6)][Tb(arene-diNOx })_{2}\right](2-\mathbf{T b})$ and $\mathrm{Tb}$ (arene-diNOx) $)_{2} \bullet \mathrm{CH}_{2} \mathrm{Cl}_{2}\left(\mathbf{3} \bullet \mathbf{C H}_{\mathbf{2}} \mathbf{C l}_{\mathbf{2}}\right) \quad \mathrm{S} 20$

Table S1. Summary of structure determination of compound $\mathrm{H}_{3}$ arene-triNOx, 1, 2'-Pr and 2-Pr.. S21

Table S2. Summary of structure determination of compound $\mathbf{2}^{\prime}-\mathbf{T b}, \mathbf{2 - T b}$ and $\mathbf{3} \cdot \mathbf{C H}_{\mathbf{2}} \mathbf{C l}_{2} \ldots \ldots \ldots \ldots . . . . . \mathrm{S} 22$ 


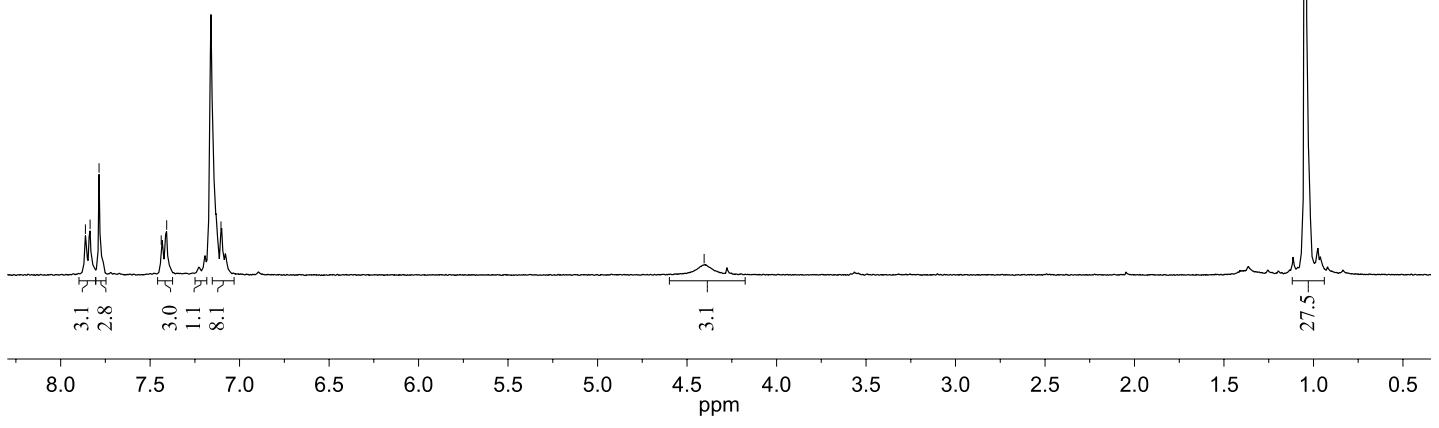

Figure S1a. ${ }^{1} \mathrm{H}$ NMR spectrum of $\mathrm{H}_{3}$ arene-triNOx in benzene- $d_{6}$.

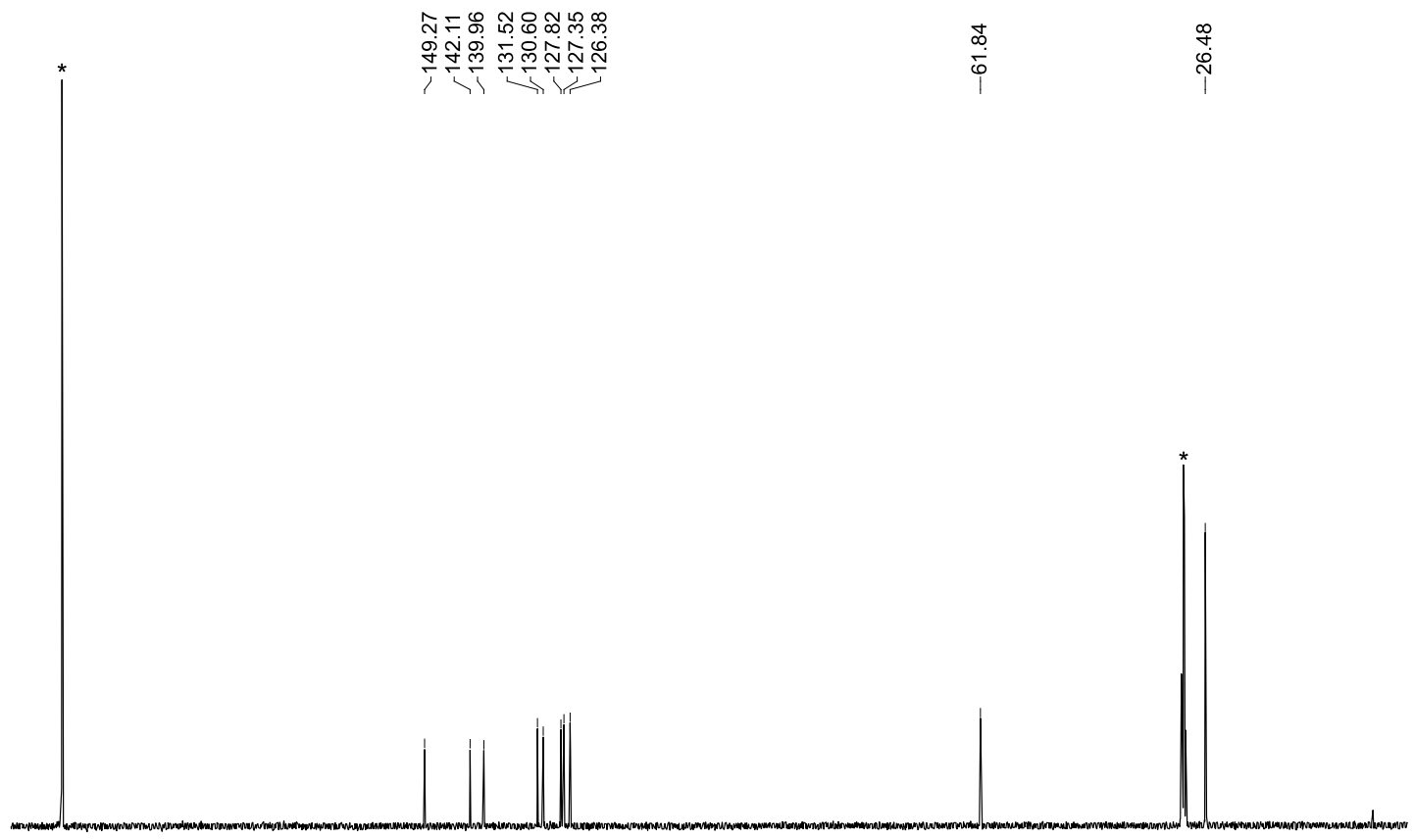

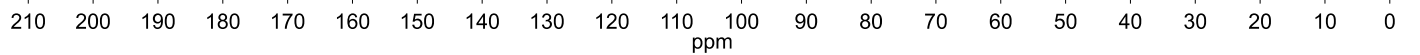

Figure S1b. ${ }^{13} \mathrm{C}$ NMR spectrum of $\mathrm{H}_{3}$ arene-triNOx in acetone- $d_{6}$ (the residual acetone peaks are indicated with *). 


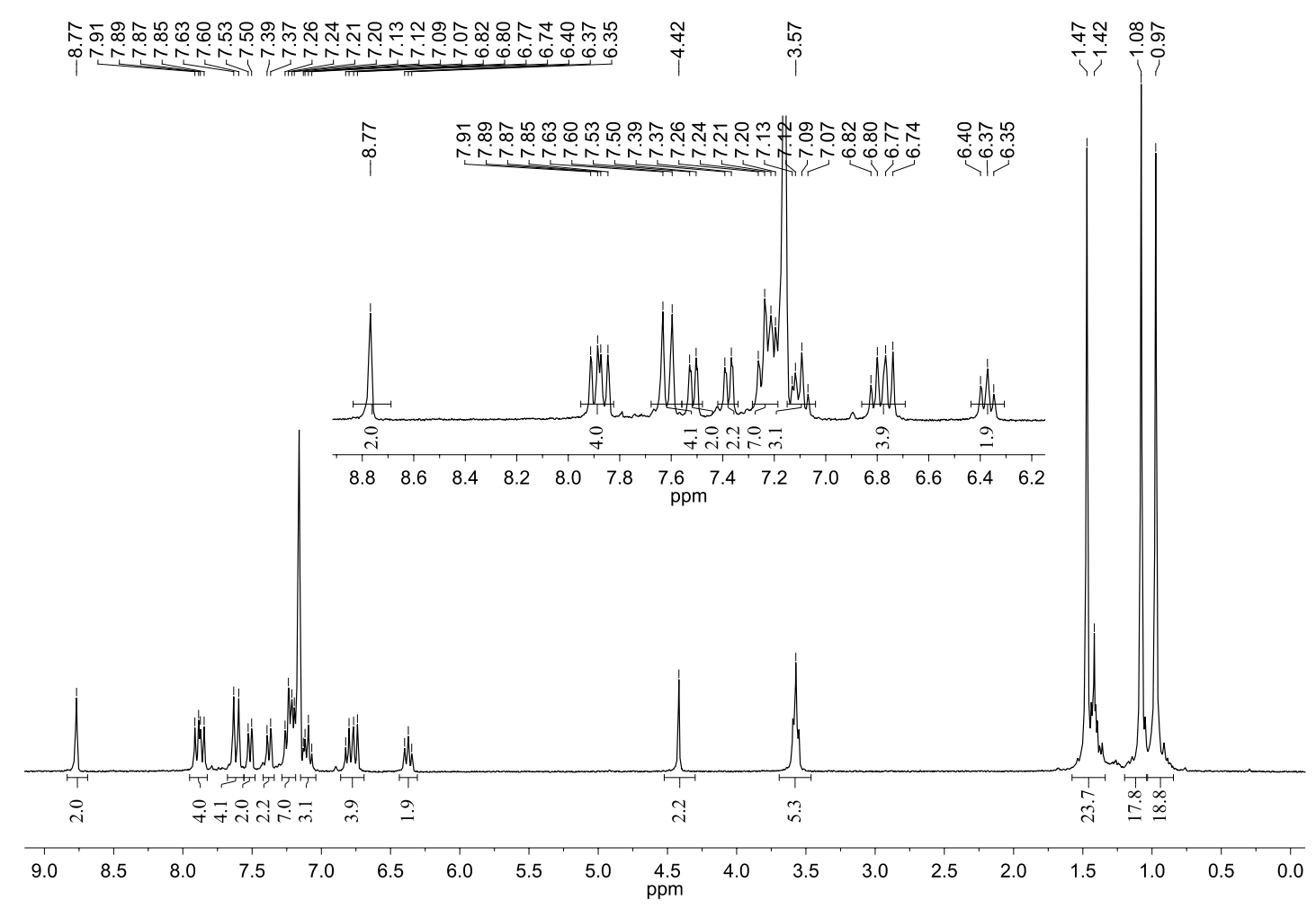

Figure S2a. ${ }^{1} \mathrm{H}$ NMR spectrum of $\mathrm{Ce}(\text { Harene-triNOx })_{2}(\mathbf{1})$ in benzene- $d_{6}$.
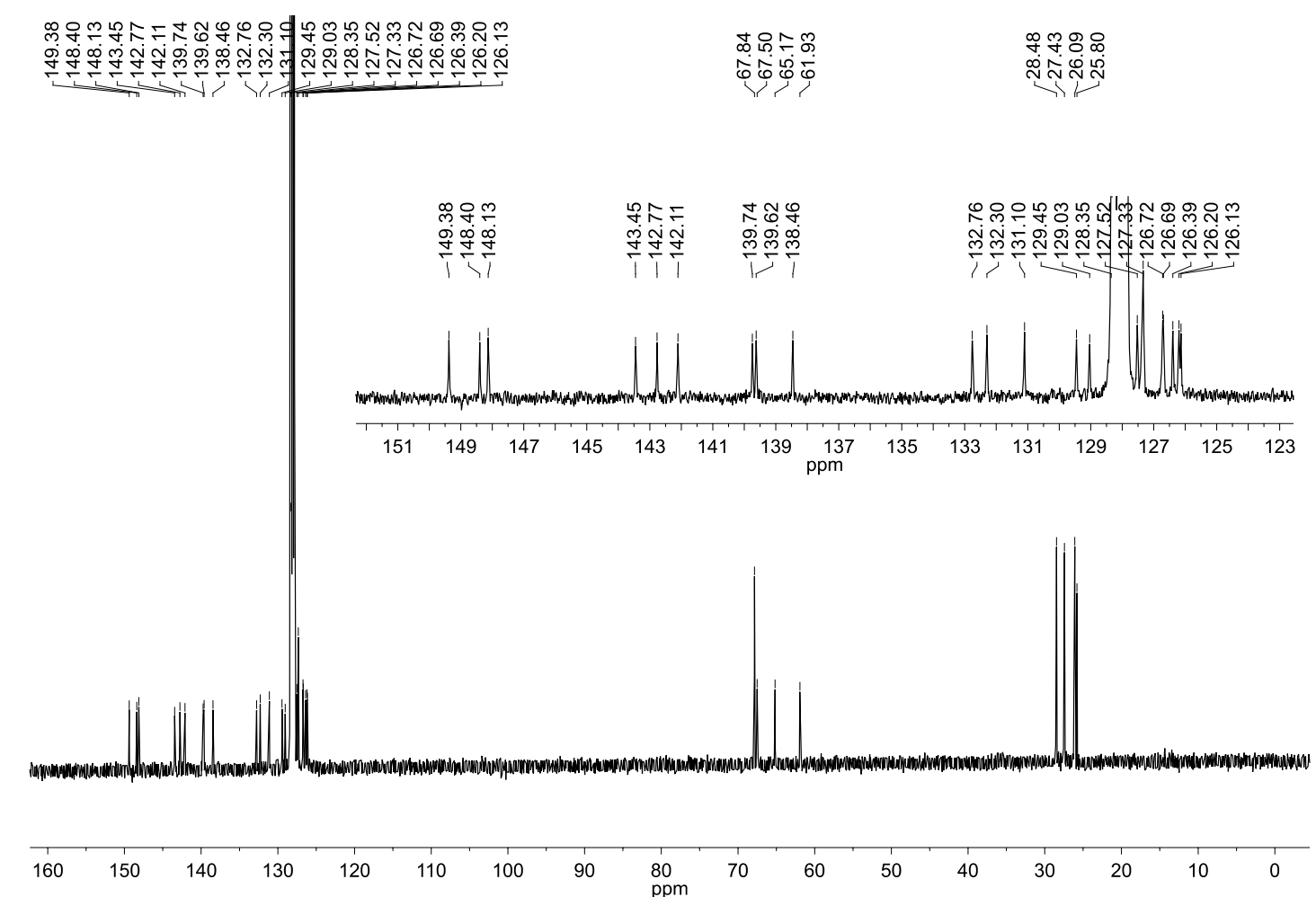

Figure S2b. ${ }^{13} \mathrm{C}$ NMR spectrum of Ce(Harene-triNOx $)_{2}(\mathbf{1})$ in benzene- $d_{6}$. 


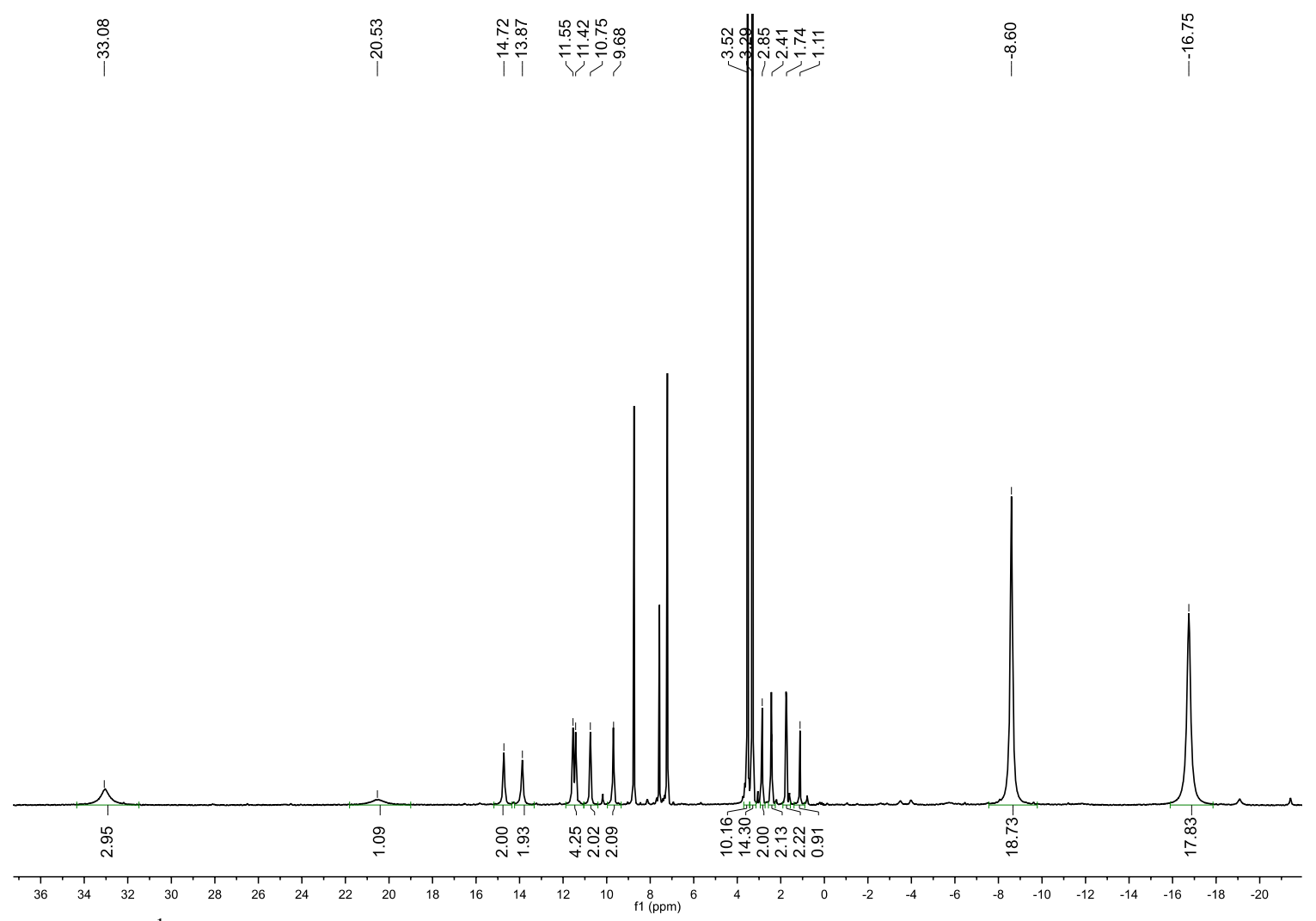

Figure S3. ${ }^{1} \mathrm{H}$ NMR spectrum of $\left[\mathrm{K}(\mathrm{DME})_{2}\right]\left[\operatorname{Pr}(\operatorname{arene}-\mathrm{diNOx})_{2}\right]\left(\mathbf{2}^{\prime}-\mathbf{P r}\right)$ in pyridine- $d_{5}$. 


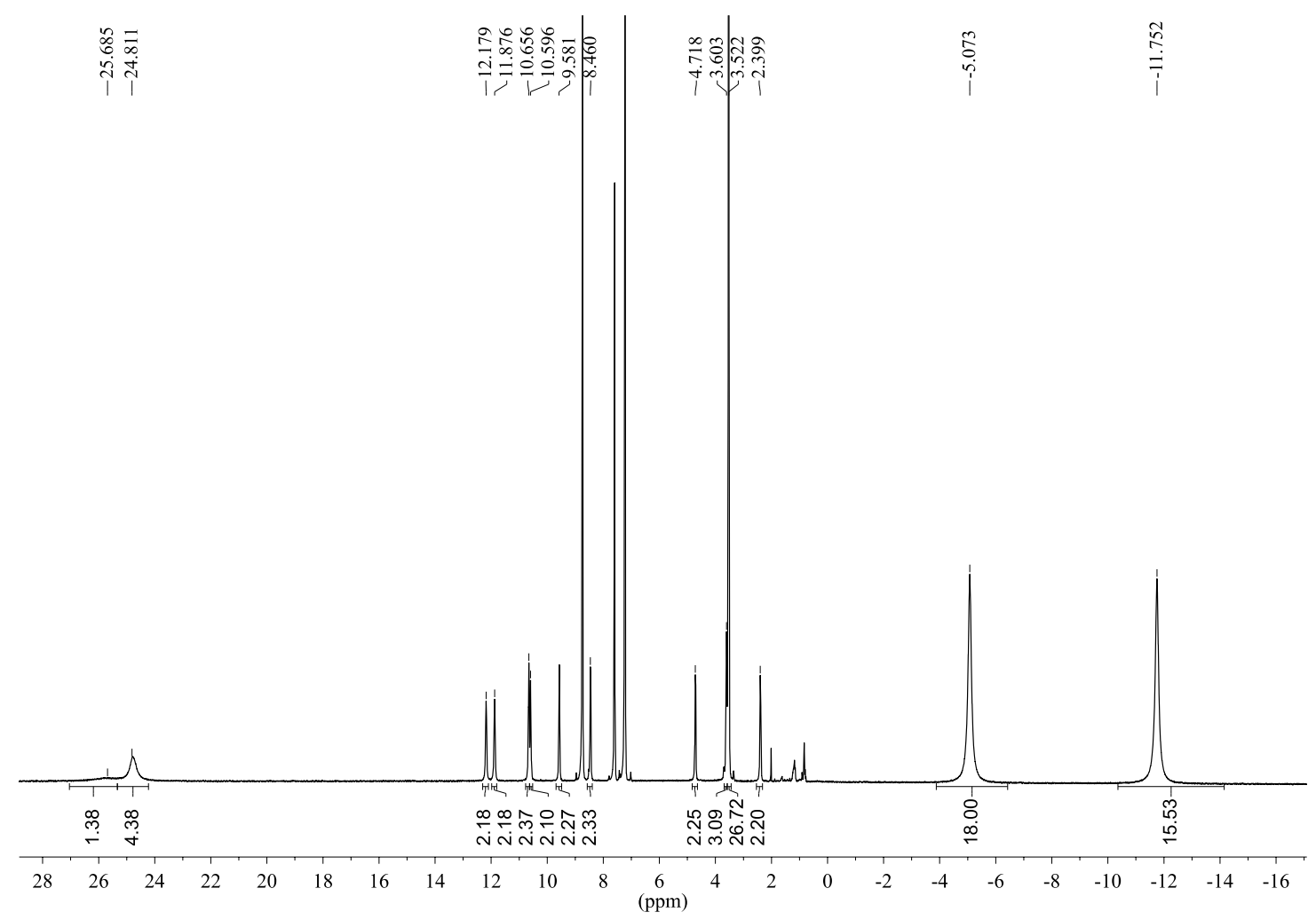

Figure S4. ${ }^{1} \mathrm{H}$ NMR spectrum of $\left[(\mathrm{py})_{2} \mathrm{~K}(18 \text {-crown-6)][Pr(arene-diNOx })_{2}\right](2-\mathrm{Pr})$ in pyridine- $d_{5}$. 


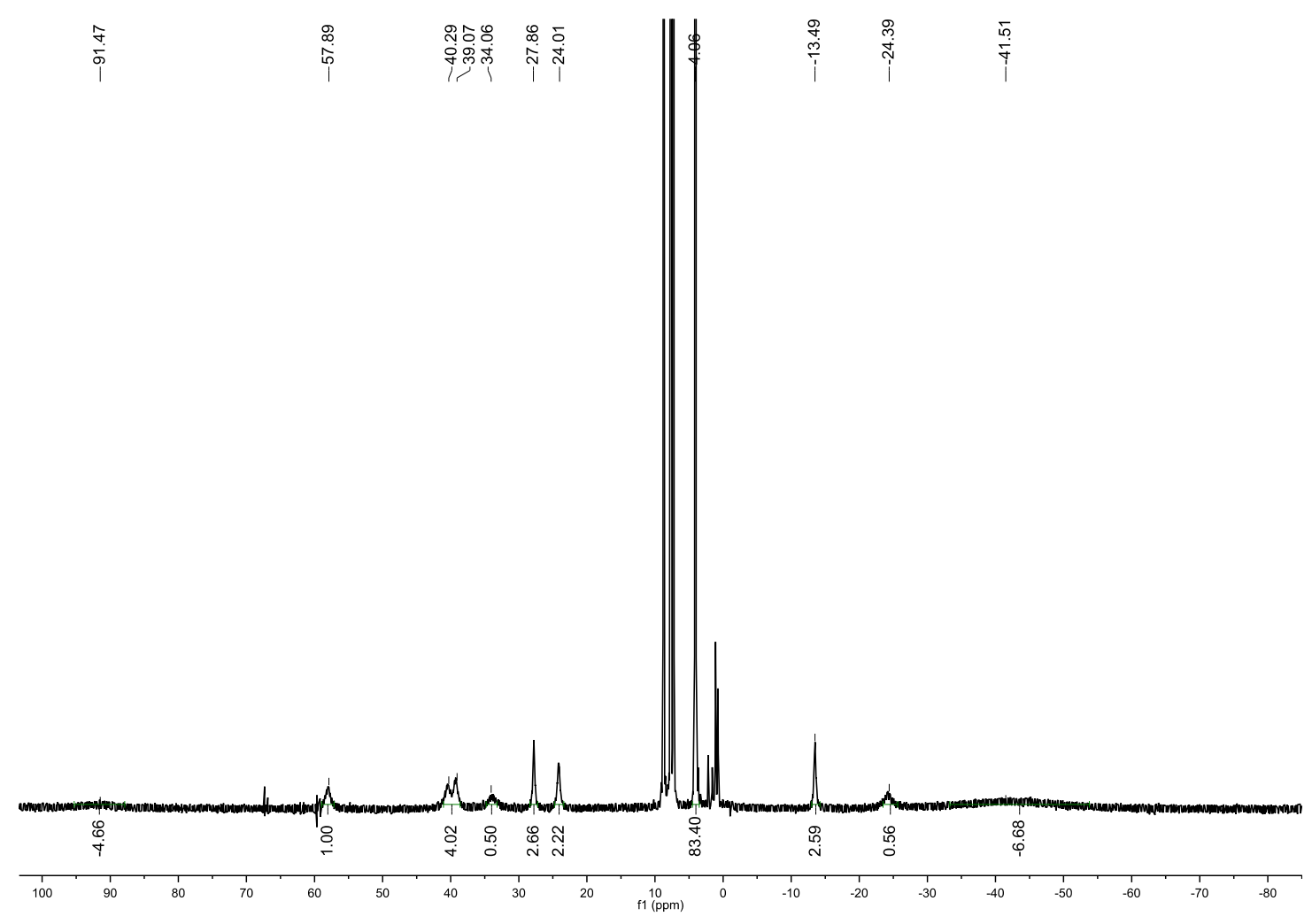

Figure S5. ${ }^{1} \mathrm{H}$ NMR spectrum of $\left[(\mathrm{py})_{2} \mathrm{~K}(18 \text {-crown-6)][Tb(arene-diNOx })_{2}\right](\mathbf{2}-\mathbf{T b})$ in pyridine- $d_{5}$. Definitive ${ }^{1} \mathrm{H}$-NMR peak integration assignments could not be made due to fast paramagnetic relaxation and broadening of the proton resonances. 


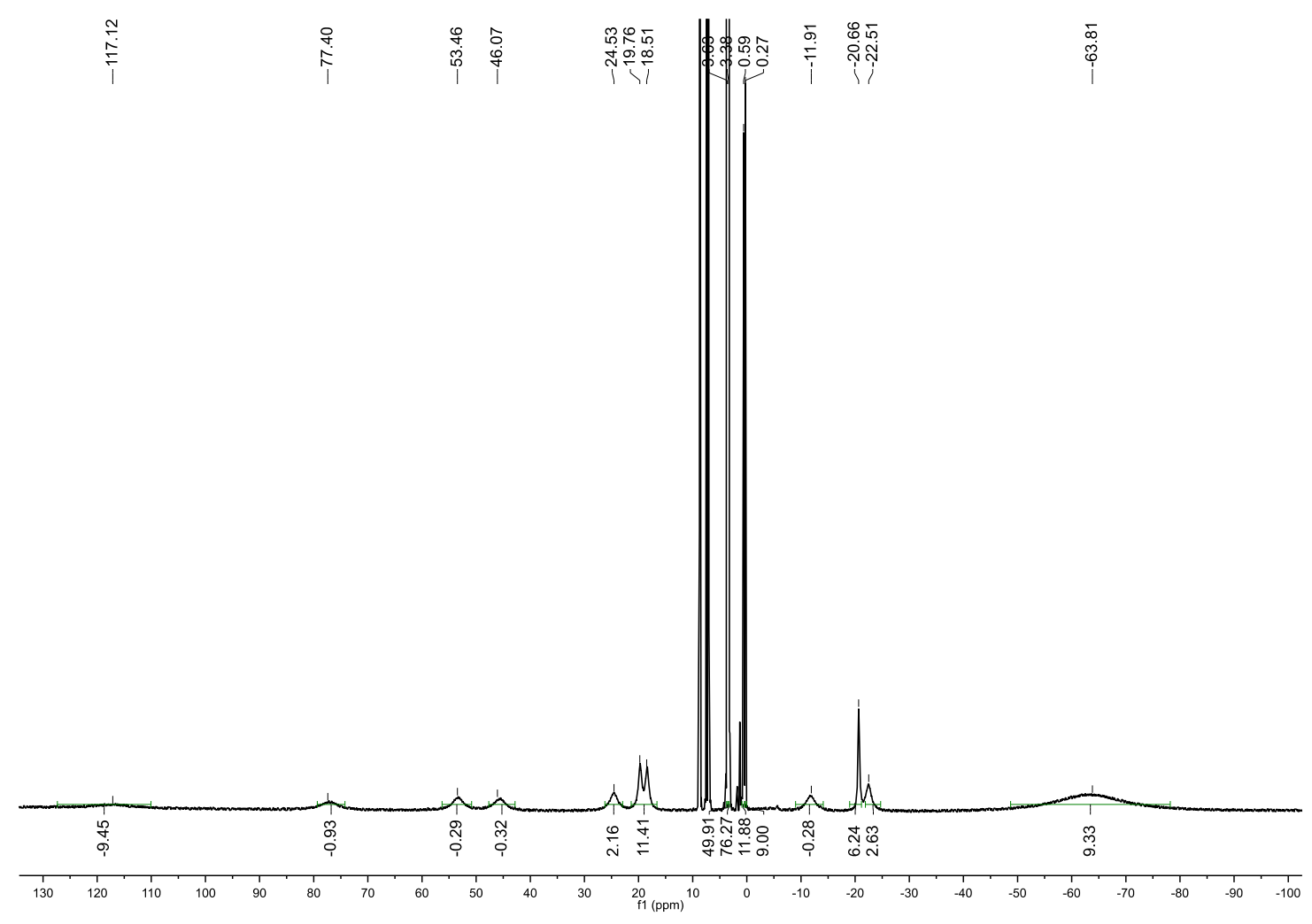

Figure S6. ${ }^{1} \mathrm{H}$ NMR spectrum of $\left[\mathrm{K}(\mathrm{DME})_{2}\right]\left[\mathrm{Tb}(\text { arene-diNOx })_{2}\right]\left(\mathbf{2}^{\prime}-\mathbf{T b}\right)$ in pyridine- $d_{5}$. Definitive ${ }^{1} \mathrm{H}-$ NMR peak integration assignments could not be made due to fast paramagnetic relaxation and broadening of the proton resonances. 


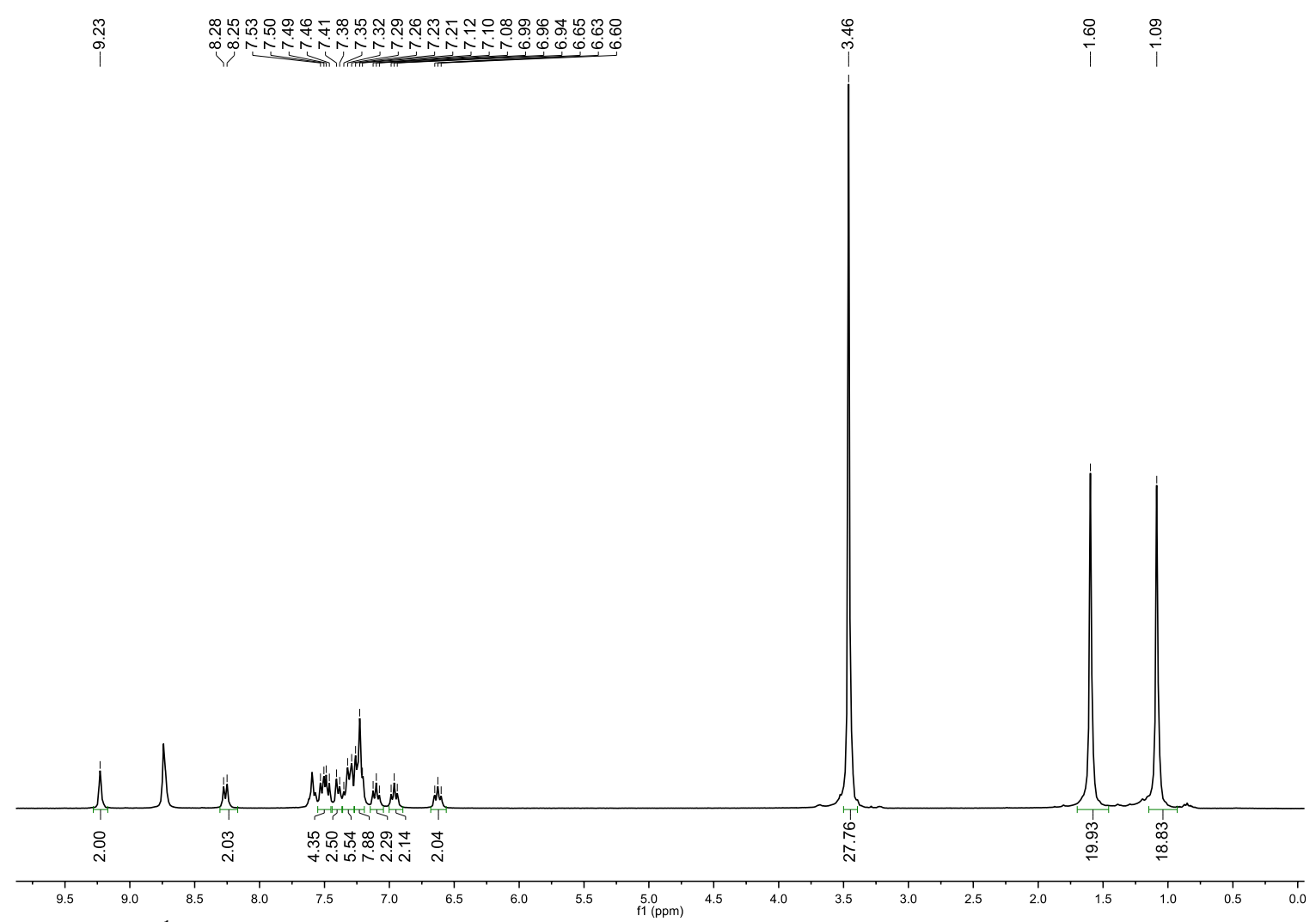

Figure S7a. ${ }^{1} \mathrm{H}$ NMR spectrum of $\left[(\mathrm{py})_{2} \mathrm{~K}(18 \text {-crown-6)][Y(arene-diNOx })_{2}\right](\mathbf{2}-\mathbf{Y})$ in pyridine- $d_{5}$.

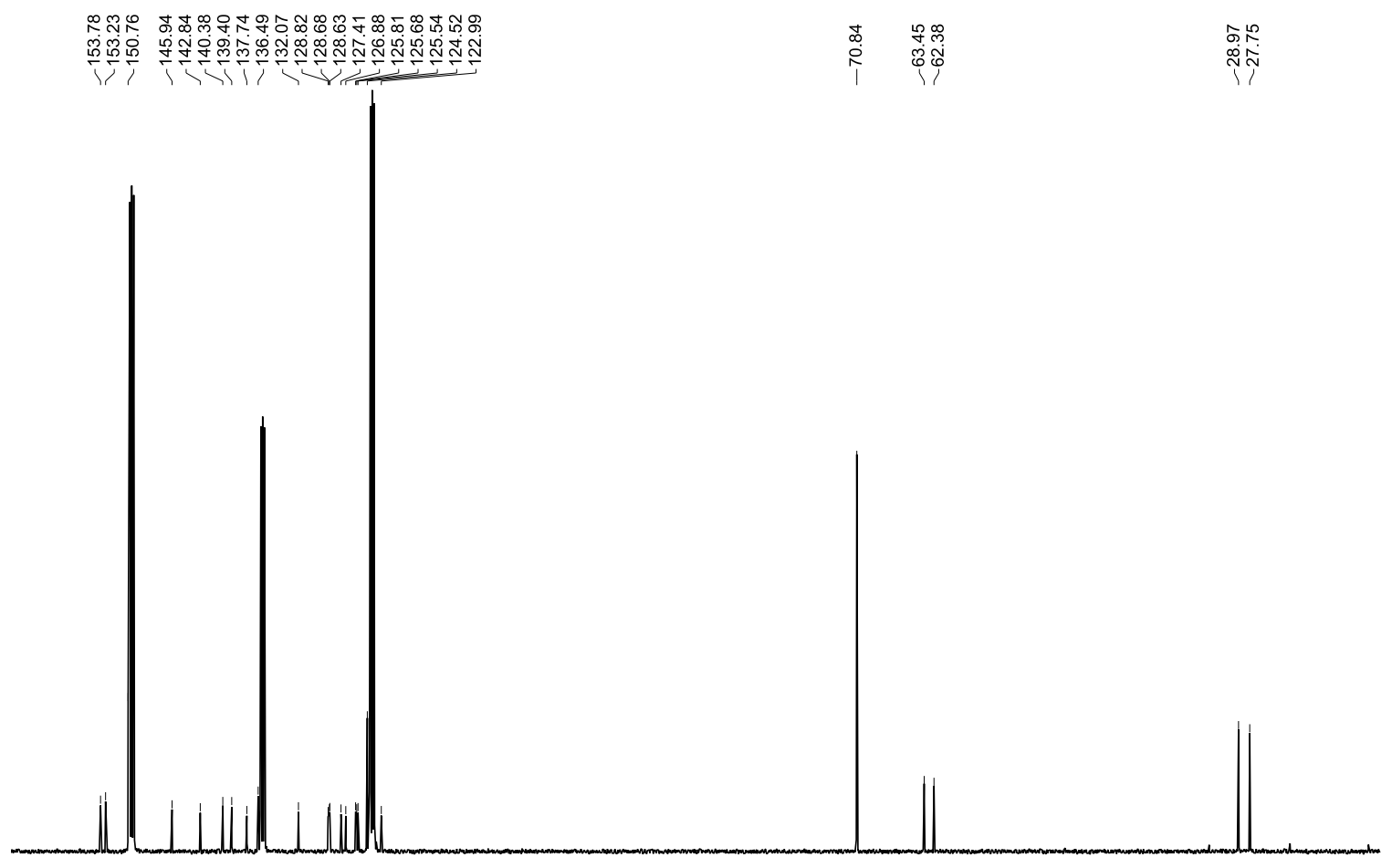

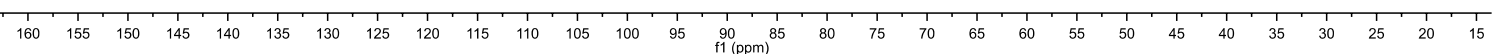

Figure S7b. ${ }^{13} \mathrm{C}$ NMR spectrum of $\left[(\mathrm{py}){ }_{2} \mathrm{~K}(18 \text {-crown-6)][Y(arene-diNOx })_{2}\right](\mathbf{2}-\mathbf{Y})$ in pyridine- $d_{5}$. 


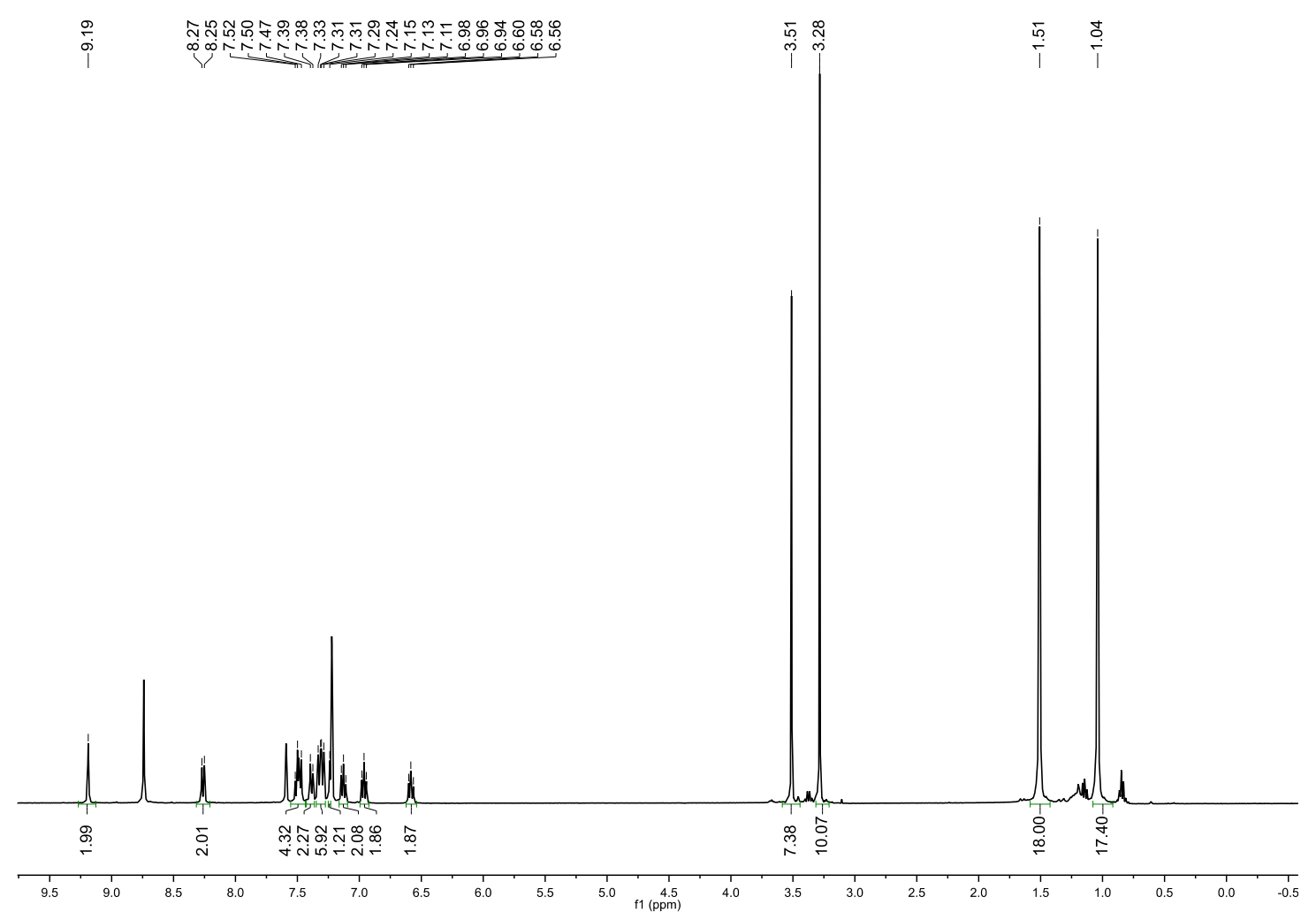

Figure S8a. ${ }^{1} \mathrm{H}$ NMR spectrum of $\left[\mathrm{K}(\mathrm{DME})_{2}\right]\left[\mathrm{Y}(\text { arene-diNOx })_{2}\right]\left(\mathbf{2}^{\prime}-\mathbf{Y}\right)$ in pyridine- $d_{5}$.
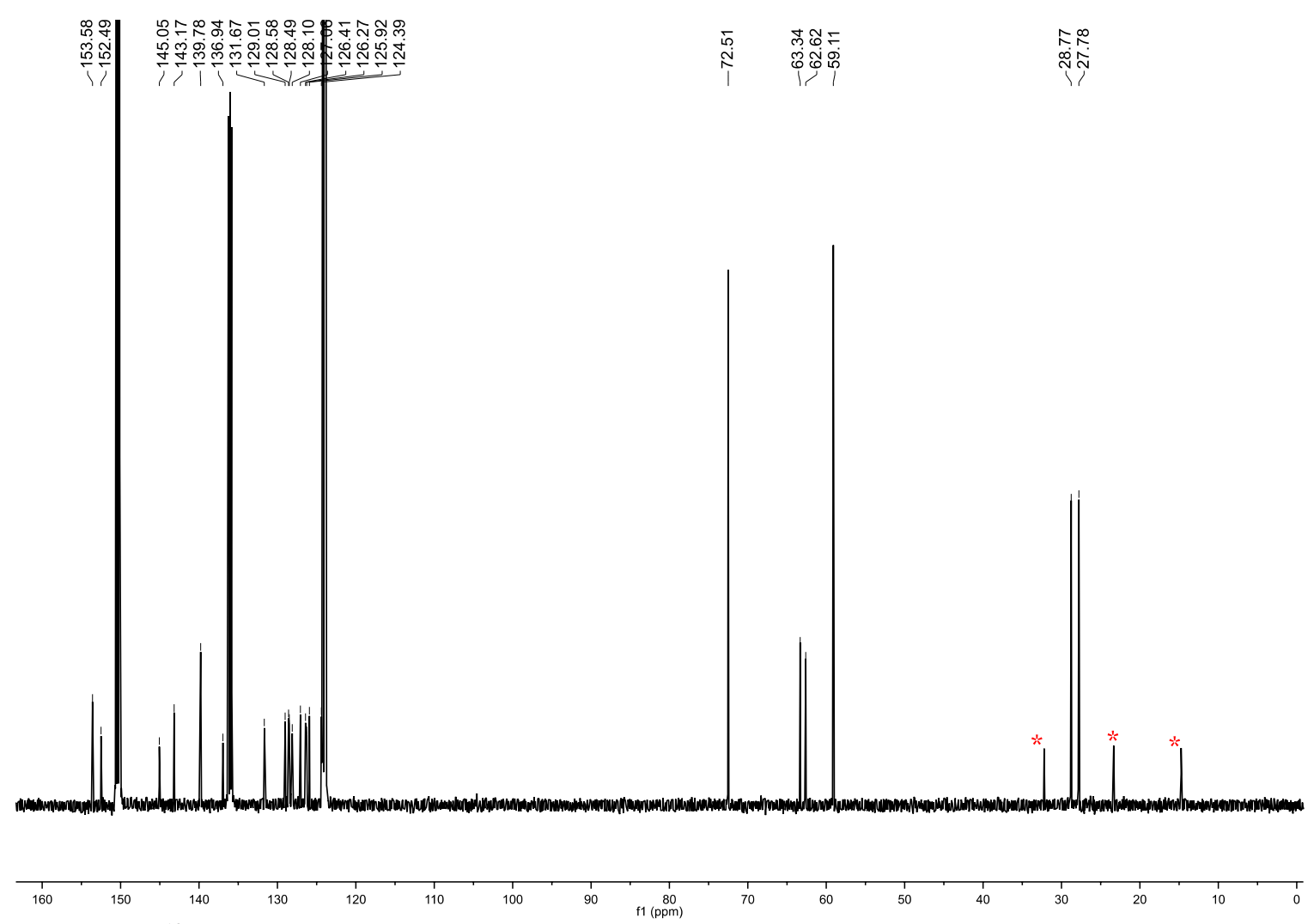

Figure S8b. ${ }^{13} \mathrm{C}$ NMR spectrum of $\left[\mathrm{K}(\mathrm{DME})_{2}\right]\left[\mathrm{Y}(\operatorname{arene}-\operatorname{diNOx})_{2}\right]\left(\mathbf{2}^{\prime}-\mathbf{Y}\right)$ in pyridine- $d_{5} \cdot{ }^{*}=$ hexanes. 


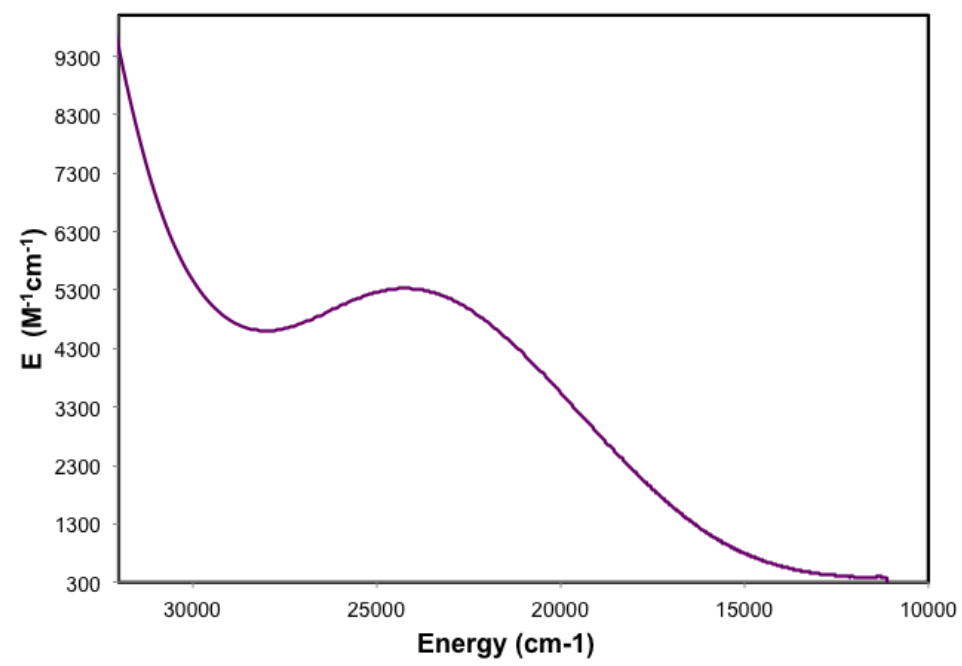

Figure S9. UV-Vis spectrum of $\mathrm{Ce}(\text { Harene-triNOx })_{2}(\mathbf{1})$ in methylene chloride showing the LMCT band.

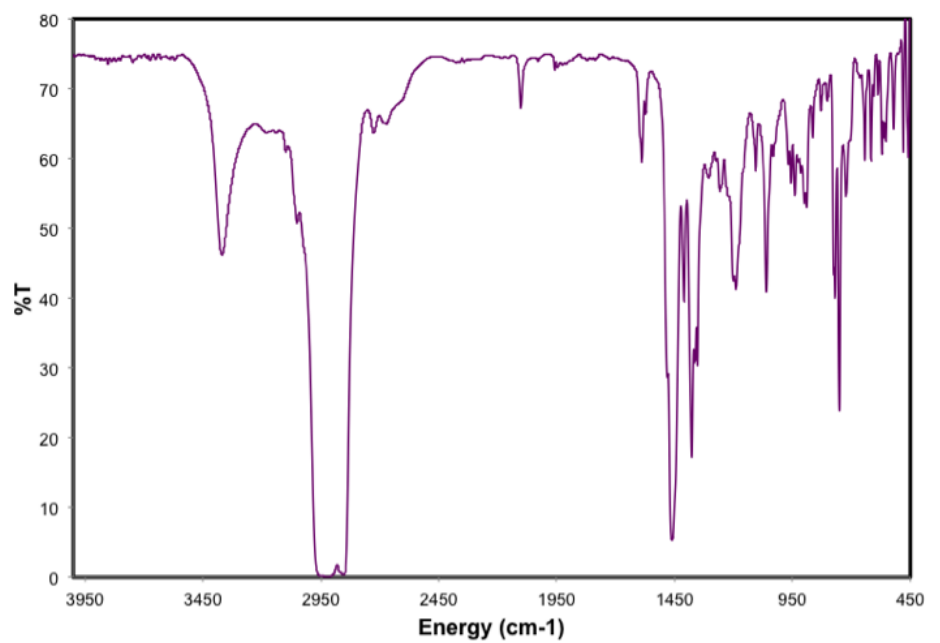

Figure S10. IR spectrum of Ce(Harene-triNOx $)_{2}(\mathbf{1})$ collected using a Nujol mull. 


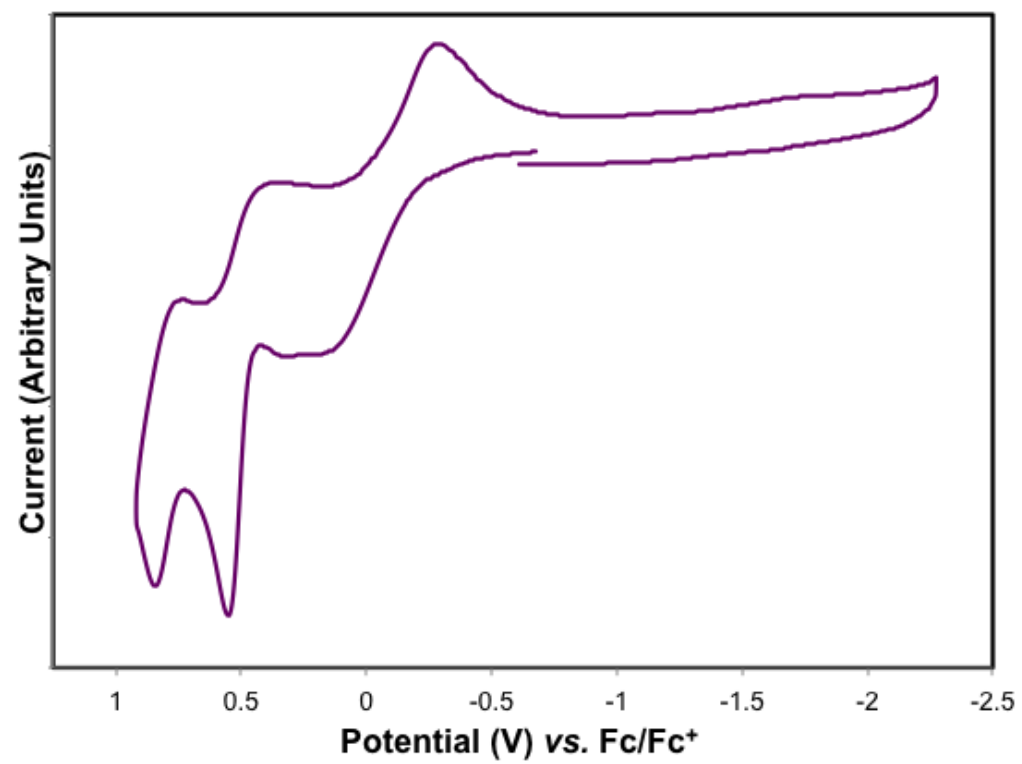

Figure $\mathrm{S} 11 \mathrm{a}$. Full scan cyclic voltammograms of $\mathrm{H}_{3}$ arene-triNOx in methylene chloride with $0.1 \mathrm{M}$ $\left[n \mathrm{Pr}_{4} \mathrm{~N}\right]\left[\mathrm{BAr}_{4}^{\mathrm{F}}\right]$ at $v=100 \mathrm{mV} / \mathrm{s}(v=$ scan rate $)$.
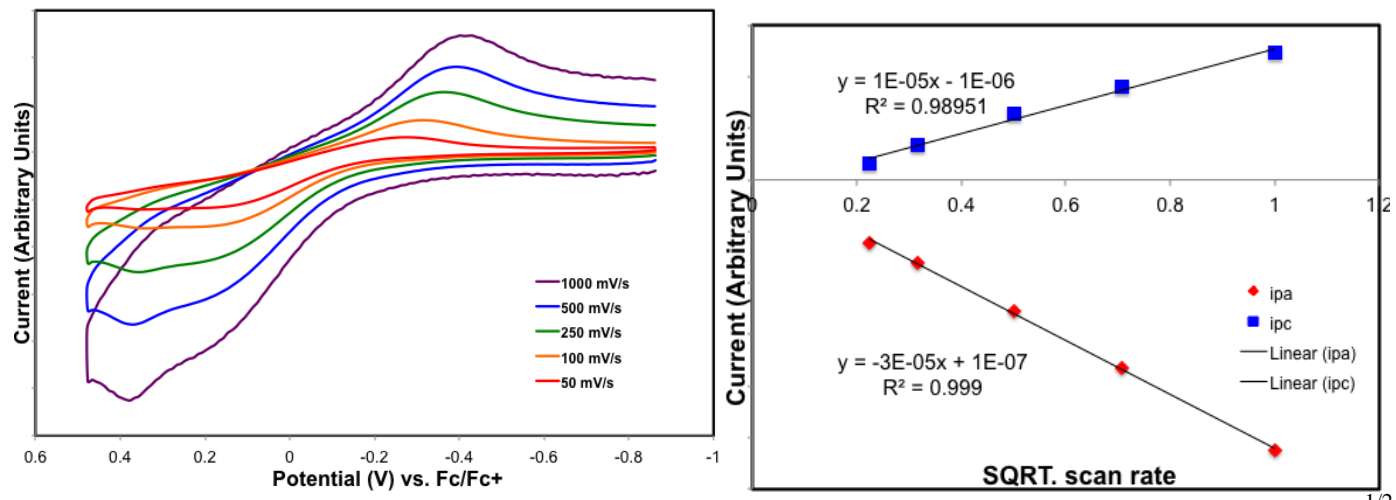

Figure S11b. Left: Isolated $[\mathrm{N}-\mathrm{OH}] /[\mathrm{N}-\mathrm{O} \bullet]$ couple at varying scan rates. Right: Current versus $v^{1 / 2}(v=$ scan rate) plot from the scan rate dependence of the isolated $[\mathrm{N}-\mathrm{OH}] /[\mathrm{N}-\mathrm{O} \bullet]$ couple. Cathodic features are shown in blue and anodic features are shown in red. Linearity shows that the redox couple is diffusion controlled according to the Randles-Sevcik equation.

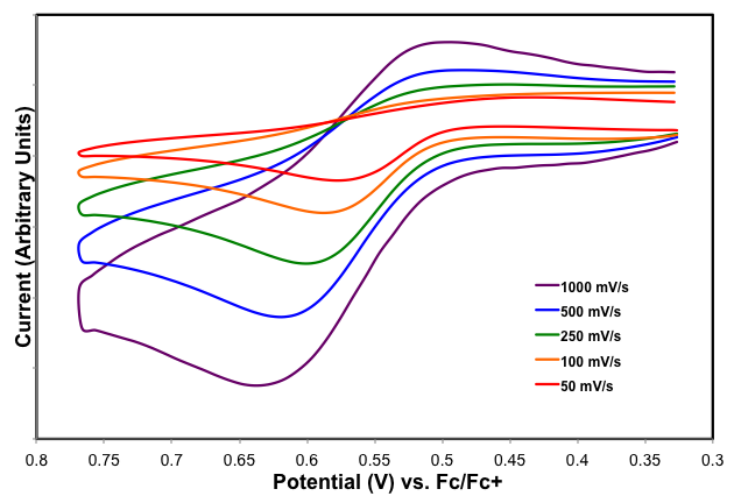

Figure $\mathrm{S} 11 \mathrm{c}$. Left: Isolated $[\mathrm{N}-\mathrm{O} \bullet] /\left[\mathrm{N}=\mathrm{O}^{+}\right]$couple at varying scan rates. 


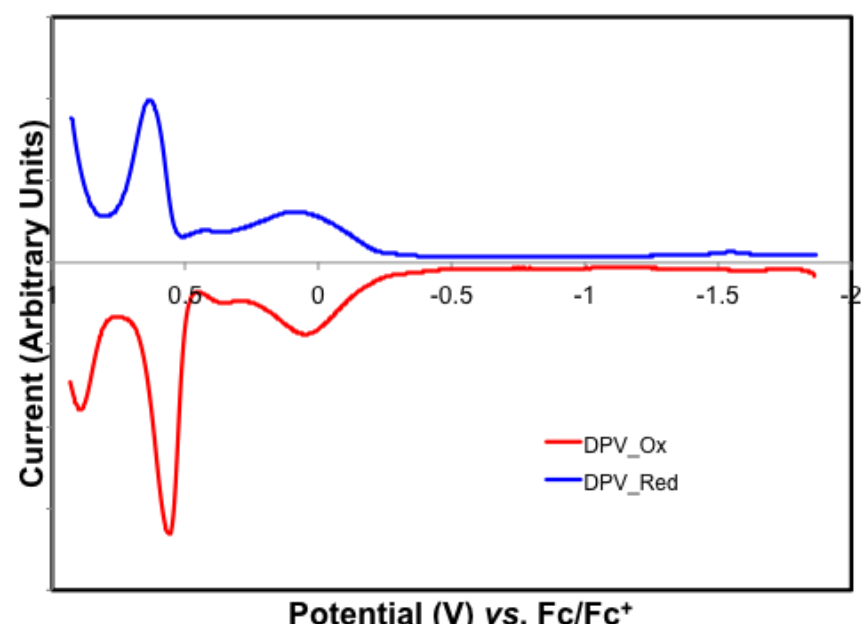

Figure S11d. Differential pulse voltammogram of $\mathrm{H}_{3}$ arene-triNOx in methylene chloride. 


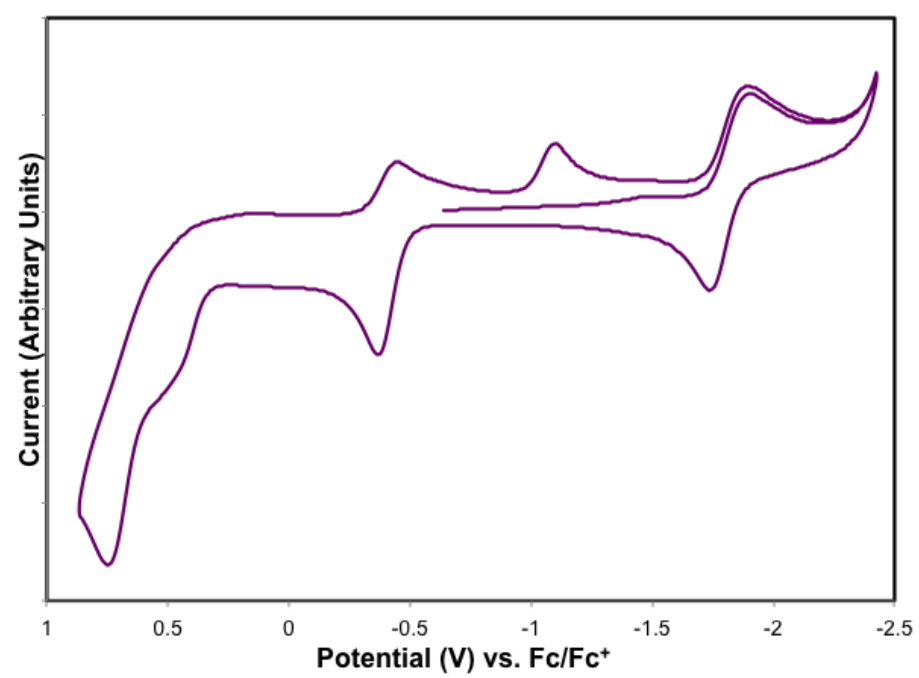

Figure S12a. Full scan cyclic voltammograms of Ce(Harene-triNOx $)_{2}(\mathbf{1})$ in methylene chloride with $0.1 \mathrm{M}$ $\left[n \mathrm{Pr}_{4} \mathrm{~N}\right]\left[\mathrm{BAr}_{4}^{\mathrm{F}}\right]$ at $\mathrm{v}=100 \mathrm{mV} / \mathrm{s}$ ( $v=$ scan rate $)$.
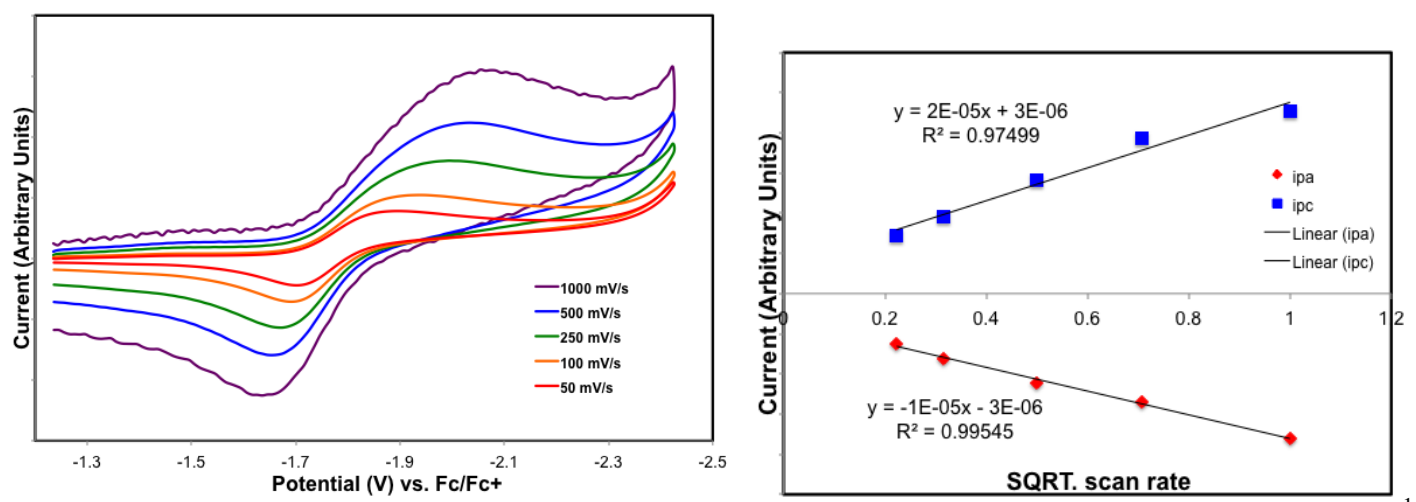

Figure S12b. Left: Isolated cerium(IV/III) redox couple at varying scan rates. Right: Current versus $v^{1 / 2}$ plot from the scan rate dependence of the isolated cerium(III/IV) couple. Cathodic features are shown in blue and anodic features are shown in red. Linearity shows that the redox couple is diffusion controlled according to the Randles-Sevcik equation.
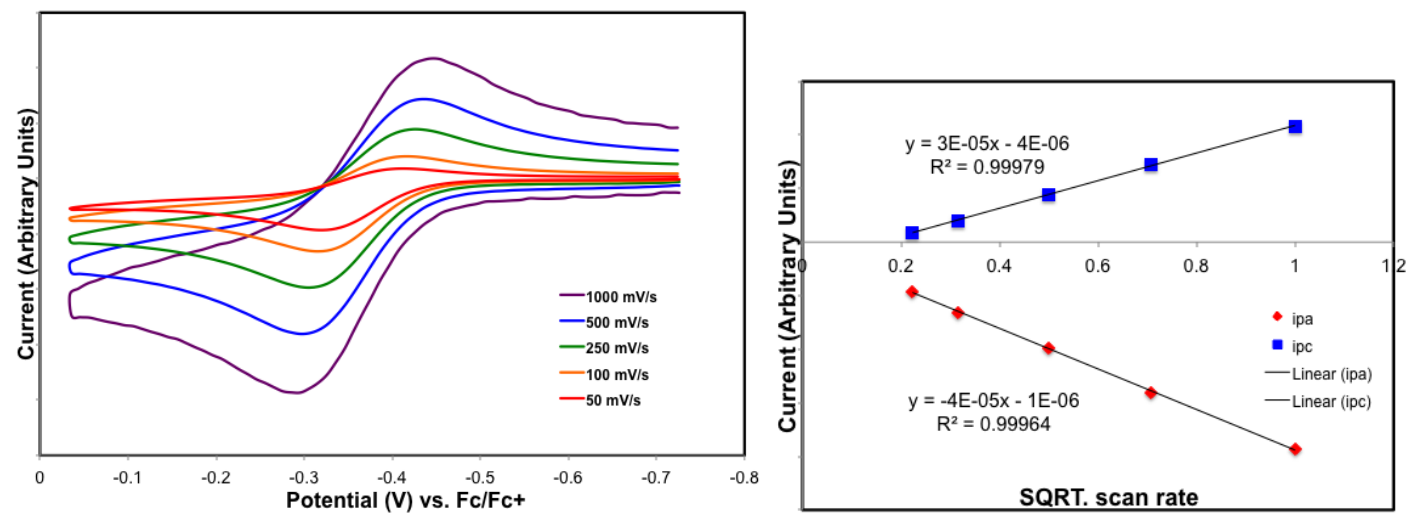

Figure S12c. Left: Isolated $\left[\mathrm{N}-\mathrm{O}^{-}\right] /[\mathrm{N}-\mathrm{O} \bullet]$ couple at varying scan rates. Right: Current versus $v^{1 / 2}(v=$ scan rate) plot from the scan rate dependence of the isolated $\left[\mathrm{N}-\mathrm{O}^{-}\right] /[\mathrm{N}-\mathrm{O} \bullet]$ couple. Cathodic features are shown in blue and anodic features are shown in red. Linearity shows that the redox couple is diffusion controlled according to the Randles-Sevcik equation. 


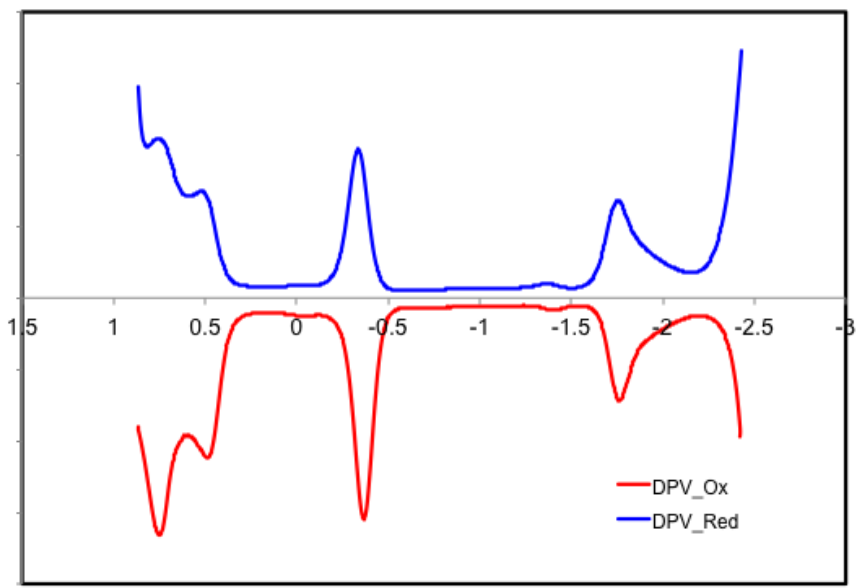

Figure S12d. Differential pulse voltammogram of $\mathrm{Ce}(\text { Harene-triNOx })_{2}(\mathbf{1})$ in methylene chloride. 


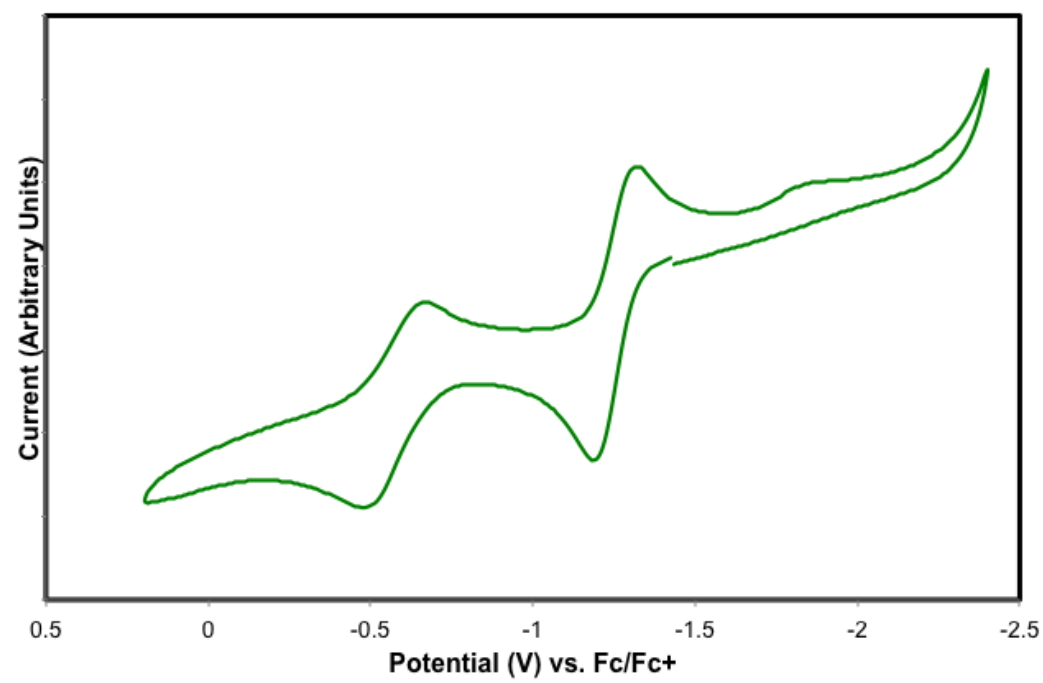

Figure S13a. Full scan cyclic voltammograms of [(py $\left.)_{2} \mathrm{~K}(18 \text {-crown-6)][Pr(arene-diNOx })_{2}\right](2-\mathbf{P r})$ in methylene chloride with $0.1 \mathrm{M}\left[n \mathrm{Pr}_{4} \mathrm{~N}\right]\left[\mathrm{BAr}_{4}^{\mathrm{F}}\right]$ at $v=100 \mathrm{mV} / \mathrm{s}$ ( $v=$ scan rate).
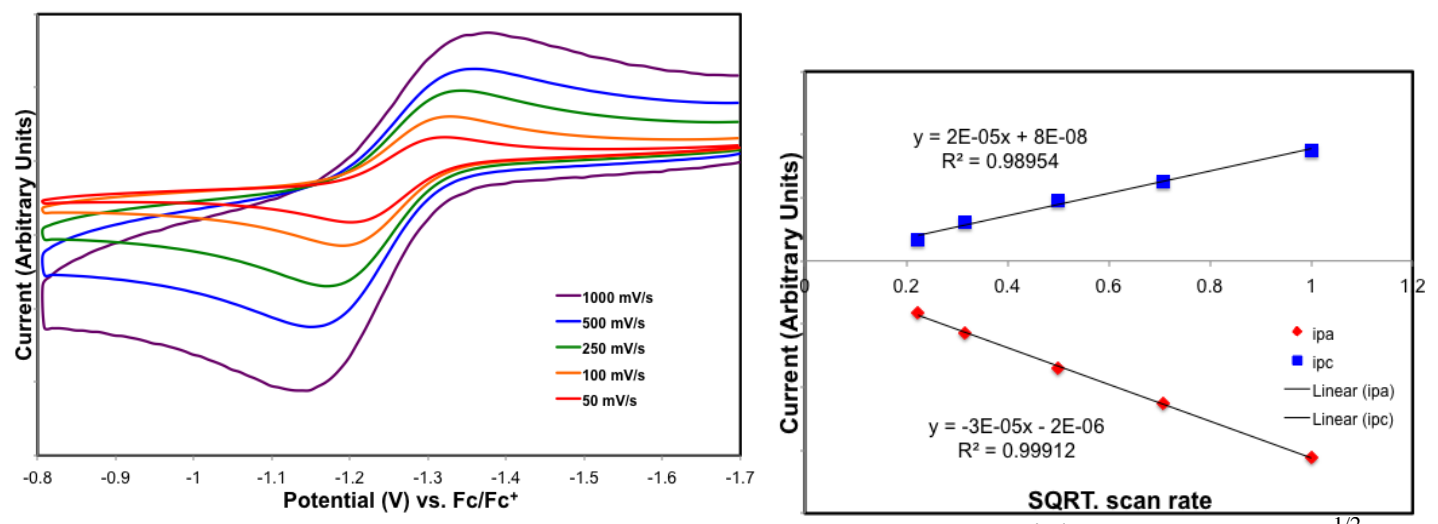

Figure S13b. Left: Isolated $\left[\mathrm{N}-\mathrm{O}^{-}\right] /[\mathrm{N}-\mathrm{O} \bullet]$ couple at varying scan rates. Right: Current versus $v^{1 / 2}(v=$ scan rate) plot from the scan rate dependence of the isolated $\left[\mathrm{N}-\mathrm{O}^{-}\right] /[\mathrm{N}-\mathrm{O} \bullet]$ couple. Cathodic features are shown in blue and anodic features are shown in red. Linearity shows that the redox couple is diffusion controlled according to the Randles-Sevcik equation.
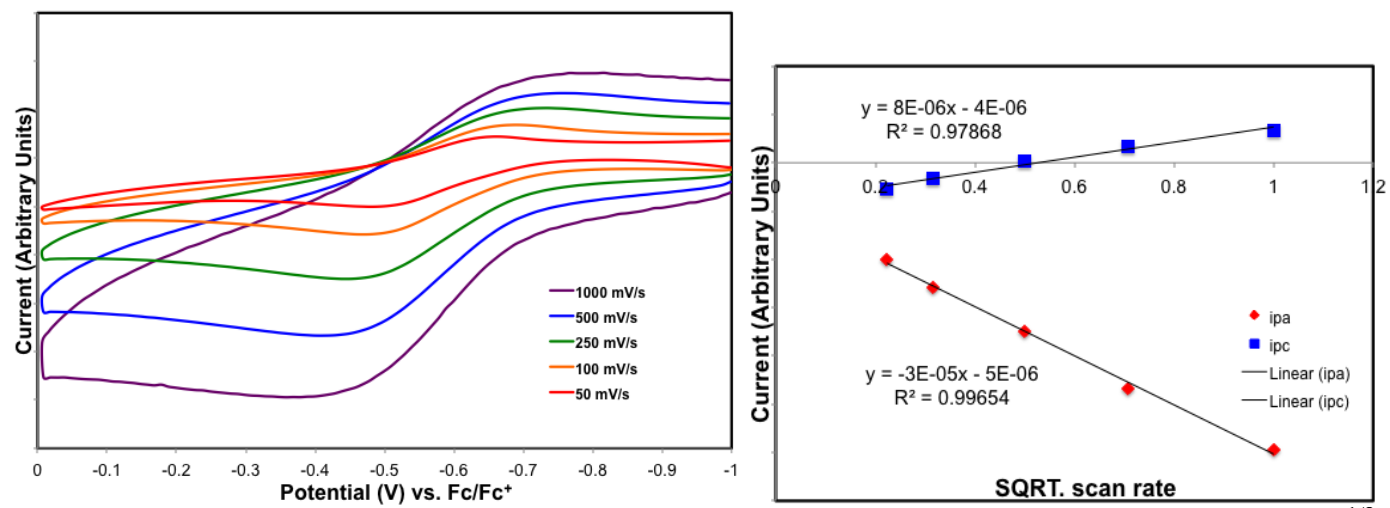

Figure S13c. Left: Isolated $\left[\mathrm{N}-\mathrm{O}^{-}\right] /\left[\mathrm{N}-\mathrm{O}^{\bullet}\right]$ couple at varying scan rates. Right: Current versus $v^{1 / 2}(v=$ scan rate) plot from the scan rate dependence of the isolated $\left[\mathrm{N}-\mathrm{O}^{-}\right] /[\mathrm{N}-\mathrm{O} \bullet]$ couple. Cathodic features are shown in blue and anodic features are shown in red. Linearity shows that the redox couple is diffusion controlled according to the Randles-Sevcik equation. 


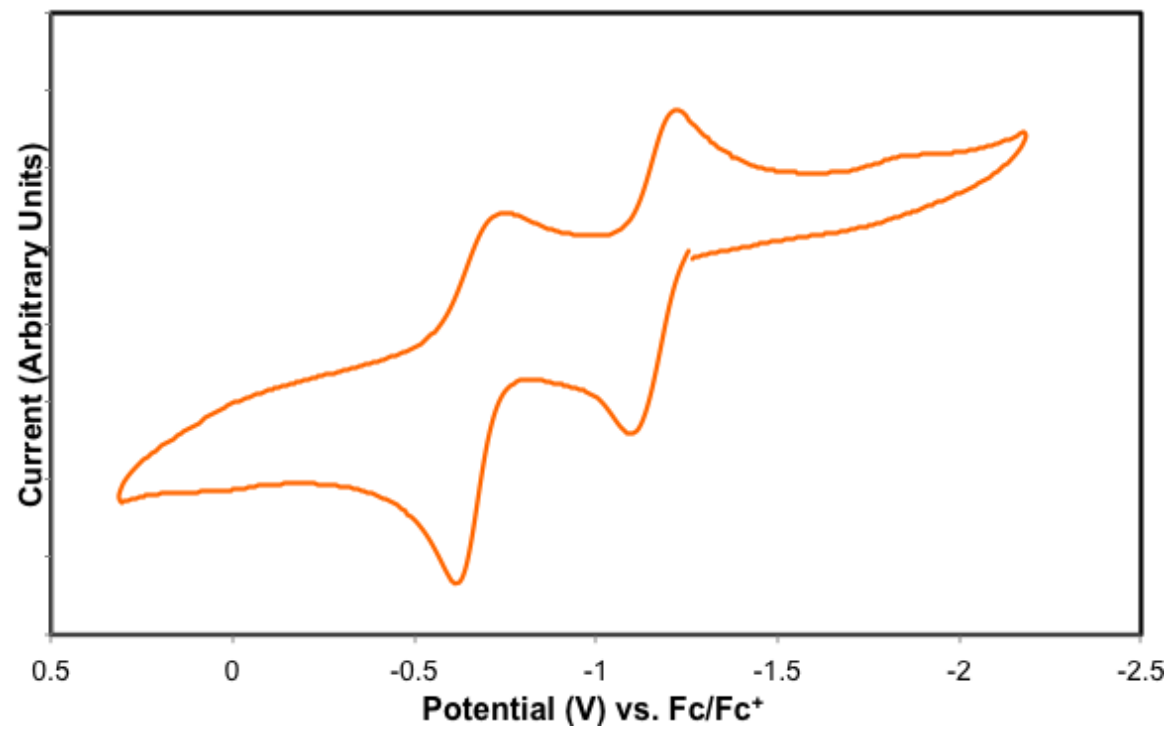

Figure S14a. Full scan cyclic voltammograms of [(py $\left.)_{2} \mathrm{~K}(18 \text {-crown-6)][Tb(arene-diNOx })_{2}\right](2-\mathbf{T b})$ in methylene chloride with $0.1 \mathrm{M}\left[n \operatorname{Pr}_{4} \mathrm{~N}\right]\left[\mathrm{BAr}_{4}\right]$ at $v=100 \mathrm{mV} / \mathrm{s}$ ( $v=$ scan rate).
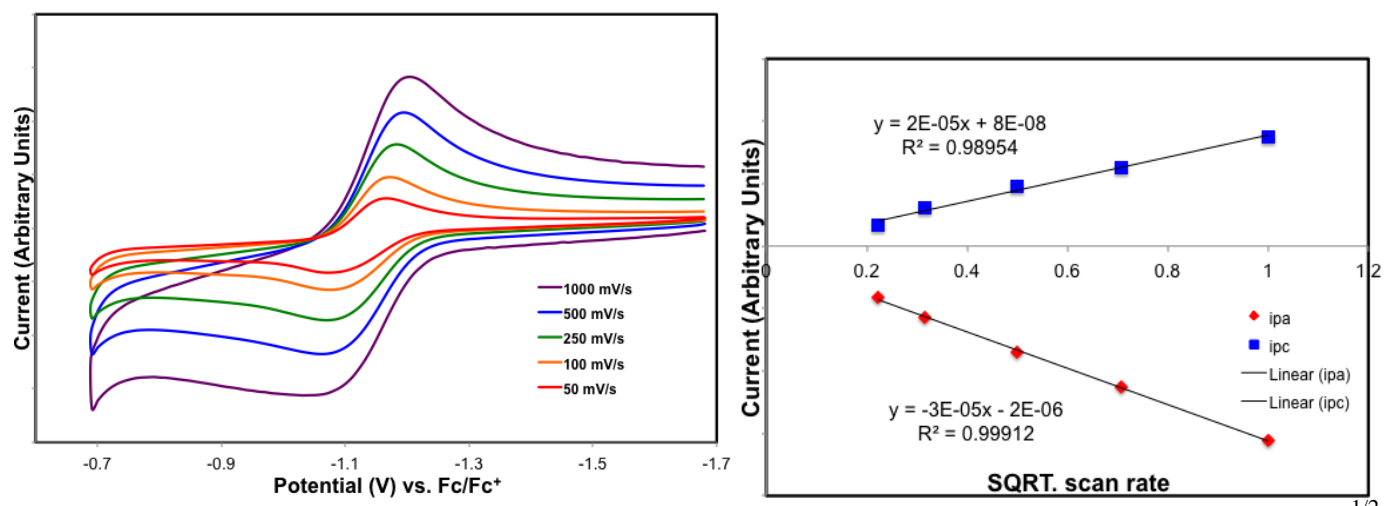

Figure S14b. Left: Isolated $\left[\mathrm{N}-\mathrm{O}^{-}\right] /[\mathrm{N}-\mathrm{O} \bullet]$ couple at varying scan rates. Right: Current versus $v^{1 / 2}(v=$ scan rate) plot from the scan rate dependence of the isolated $\left[\mathrm{N}^{-} \mathrm{O}^{-}\right] /[\mathrm{N}-\mathrm{O} \bullet]$ couple. Cathodic features are shown in blue and anodic features are shown in red. Linearity shows that the redox couple is diffusion controlled according to the Randles-Sevcik equation.
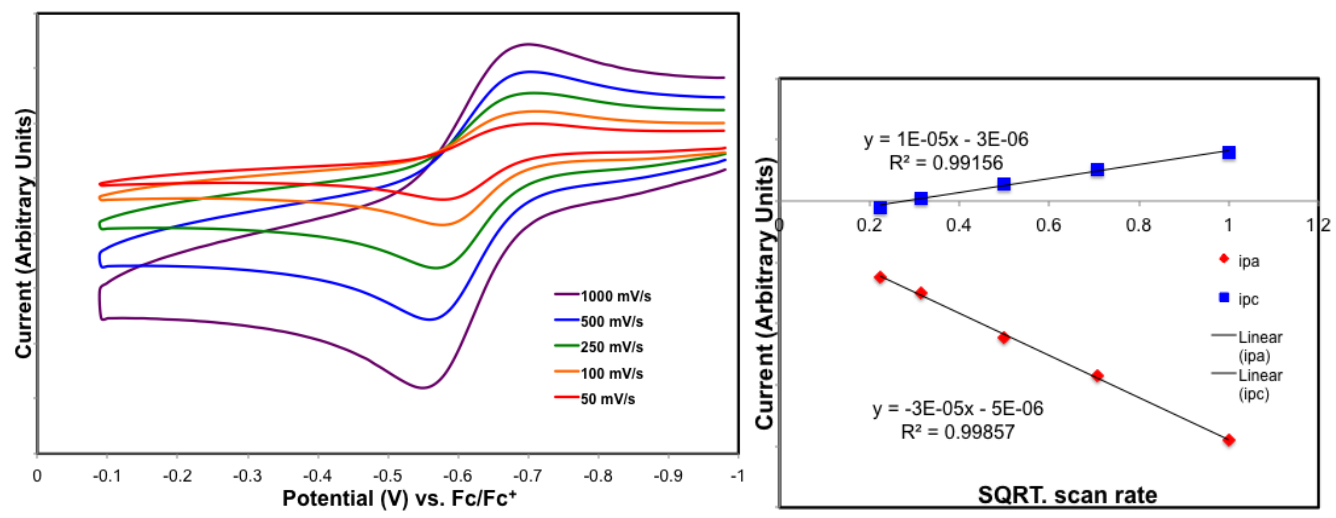

Figure S14c. Left: Isolated $\left[\mathrm{N}-\mathrm{O}^{-}\right] /[\mathrm{N}-\mathrm{O} \bullet]$ couple at varying scan rates. Right: Current versus $v^{1 / 2}(v=$ scan rate) plot from the scan rate dependence of the isolated $\left[\mathrm{N}-\mathrm{O}^{-}\right] /[\mathrm{N}-\mathrm{O} \bullet]$ couple. Cathodic features are shown in blue and anodic features are shown in red. Linearity shows that the redox couple is diffusion controlled according to the Randles-Sevcik equation. 


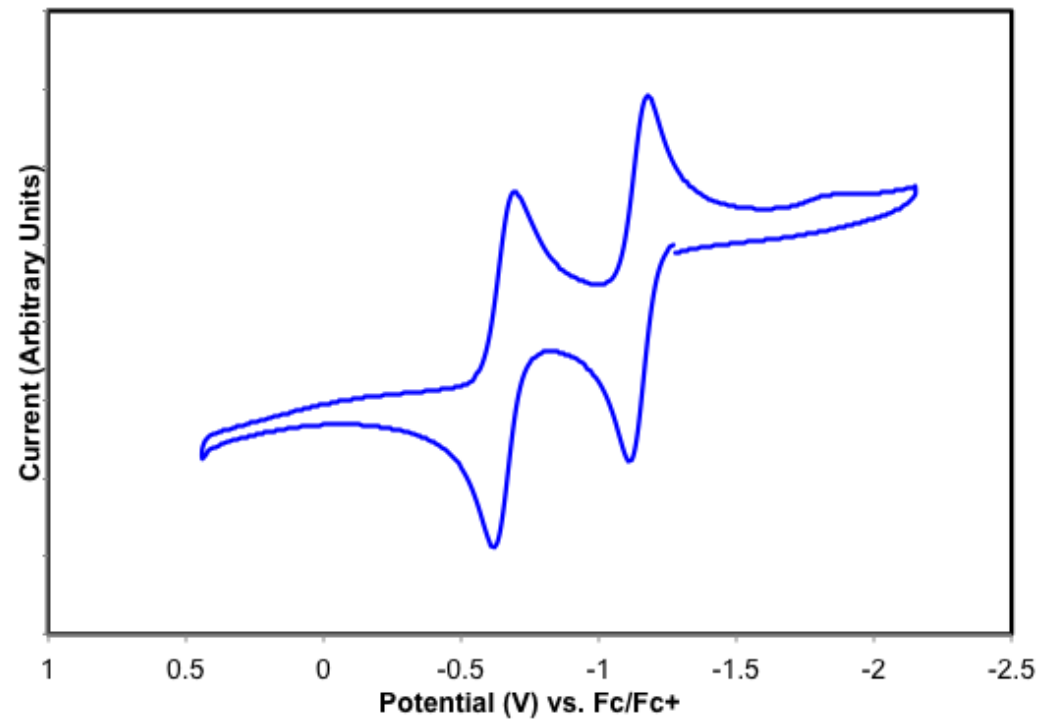

Figure S15a. Full scan cyclic voltammograms of $\left[(\mathrm{py})_{2} \mathrm{~K}(18 \text {-crown-6)][Y(arene-diNOx })_{2}\right](\mathbf{2}-\mathbf{Y})$ in methylene chloride with $0.1 \mathrm{M}\left[n \operatorname{Pr}_{4} \mathrm{~N}\right]\left[\mathrm{BAr}_{4}^{\mathrm{F}}\right]$ at $v=100 \mathrm{mV} / \mathrm{s}$ ( $v=$ scan rate).
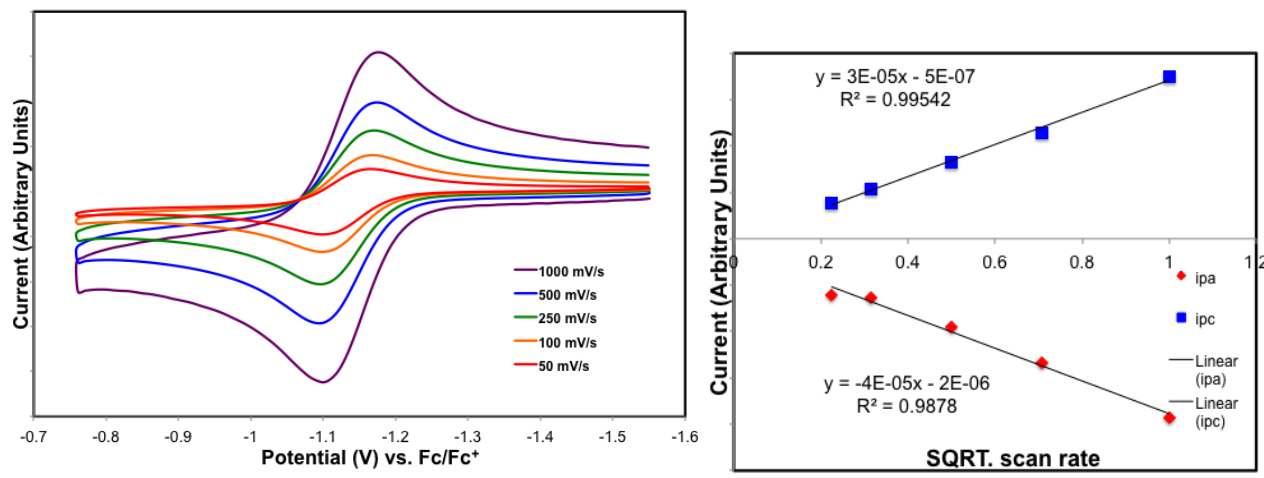

Figure S15b. Left: Isolated $\left[\mathrm{N}-\mathrm{O}^{-}\right] /[\mathrm{N}-\mathrm{O} \bullet]$ couple at varying scan rates. Right: Current versus $v^{1 / 2}(v=$ scan rate) plot from the scan rate dependence of the isolated $\left[\mathrm{N}^{-} \mathrm{O}^{-}\right] /[\mathrm{N}-\mathrm{O} \bullet]$ couple. Cathodic features are shown in blue and anodic features are shown in red. Linearity shows that the redox couple is diffusion controlled according to the Randles-Sevcik equation.
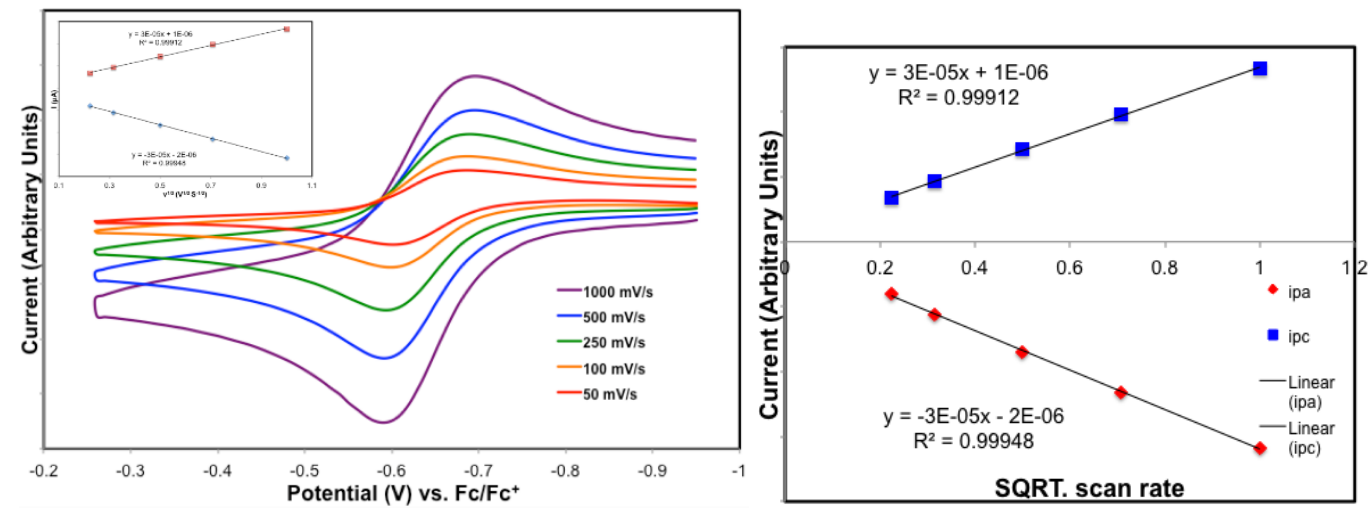

Figure S15c. Left: Isolated $\left[\mathrm{N}-\mathrm{O}^{-}\right] /[\mathrm{N}-\mathrm{O} \bullet]$ couple at varying scan rates. Right: Current versus $v^{1 / 2}(v=$ scan rate) plot from the scan rate dependence of the isolated $\left[\mathrm{N}-\mathrm{O}^{-}\right] /[\mathrm{N}-\mathrm{O} \bullet]$ couple. Cathodic features are shown in blue and anodic features are shown in red. Linearity shows that the redox couple is diffusion controlled according to the Randles-Sevcik equation. 

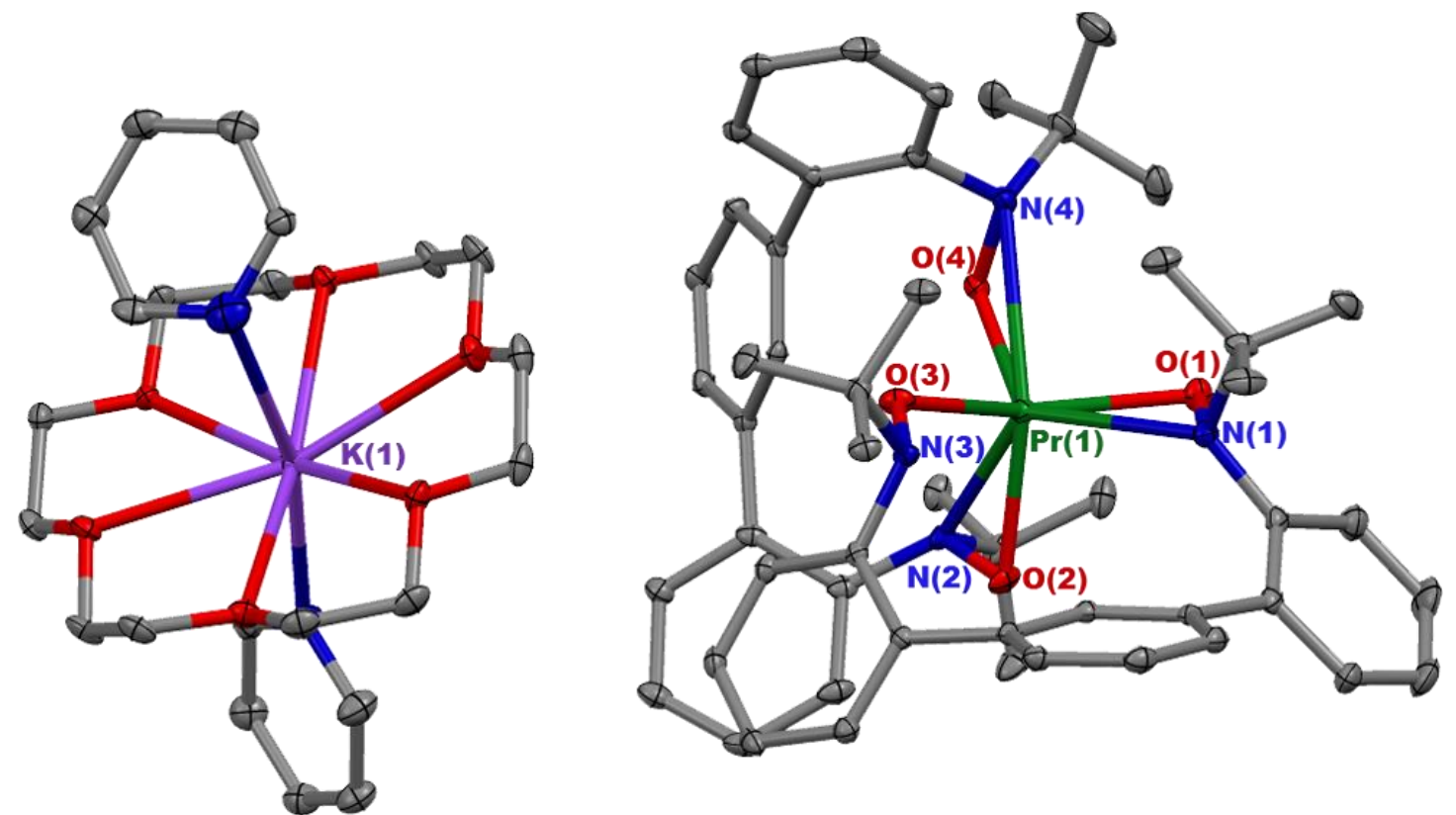

Figure S16. Thermal ellipsoid plot of $\left[(\mathrm{py})_{2} \mathrm{~K}(18 \text {-crown-6)][Pr(arene-diNOx })_{2}\right](2-\mathbf{P r})$ at $30 \%$ probability. Hydrogen atoms and interstitial solvents were omitted for clarity.
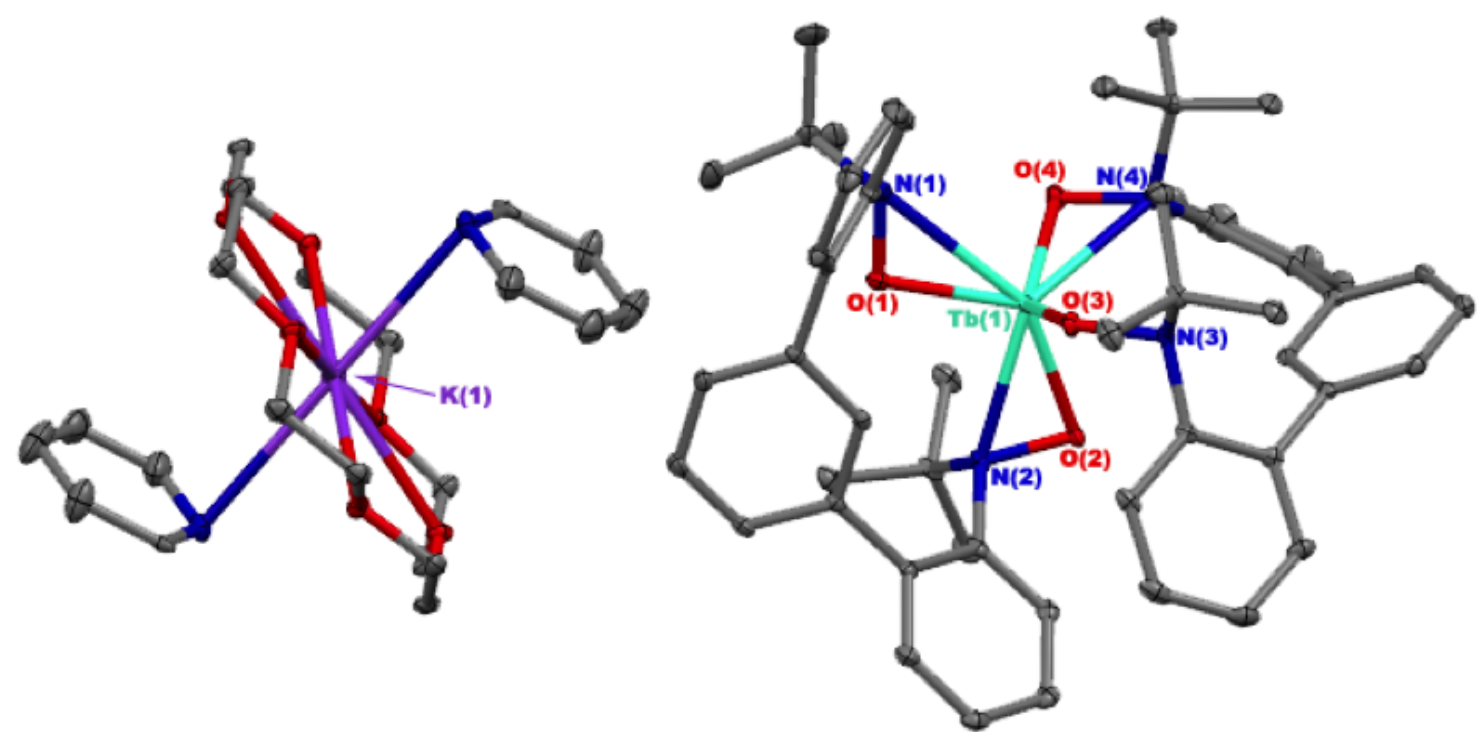

Figure S17. Thermal ellipsoid plot of $\left[(\mathrm{py})_{2} \mathrm{~K}(18 \text {-crown-6)][Tb(arene-diNOx })_{2}\right](\mathbf{2}-\mathbf{T b})$ at $30 \%$ probability. Hydrogen atoms and interstitial solvents were omitted for clarity. Selected bond distances: $\mathrm{Tb}(1)-\mathrm{O}(1)$ 2.210(3) $\AA$, $\mathrm{Tb}(1)-\mathrm{O}(2) 2.219(3) \AA, \mathrm{Tb}(1)-\mathrm{O}(3)$ 2.183(3) $\AA$, $\mathrm{Tb}(1)-\mathrm{O}(4) 2.207(3) \AA ̊ ., \mathrm{N}(1)-\mathrm{O}(1)$ 1.429(4) $\AA, \mathrm{N}(2)-\mathrm{O}(2) 1.451(4) \AA, \mathrm{N}(3)-\mathrm{O}(3) 1.439(4) \AA ⿻ \mathrm{~A}, \mathrm{~N}(4)-\mathrm{O}(4) 1.444(4) \AA$. 


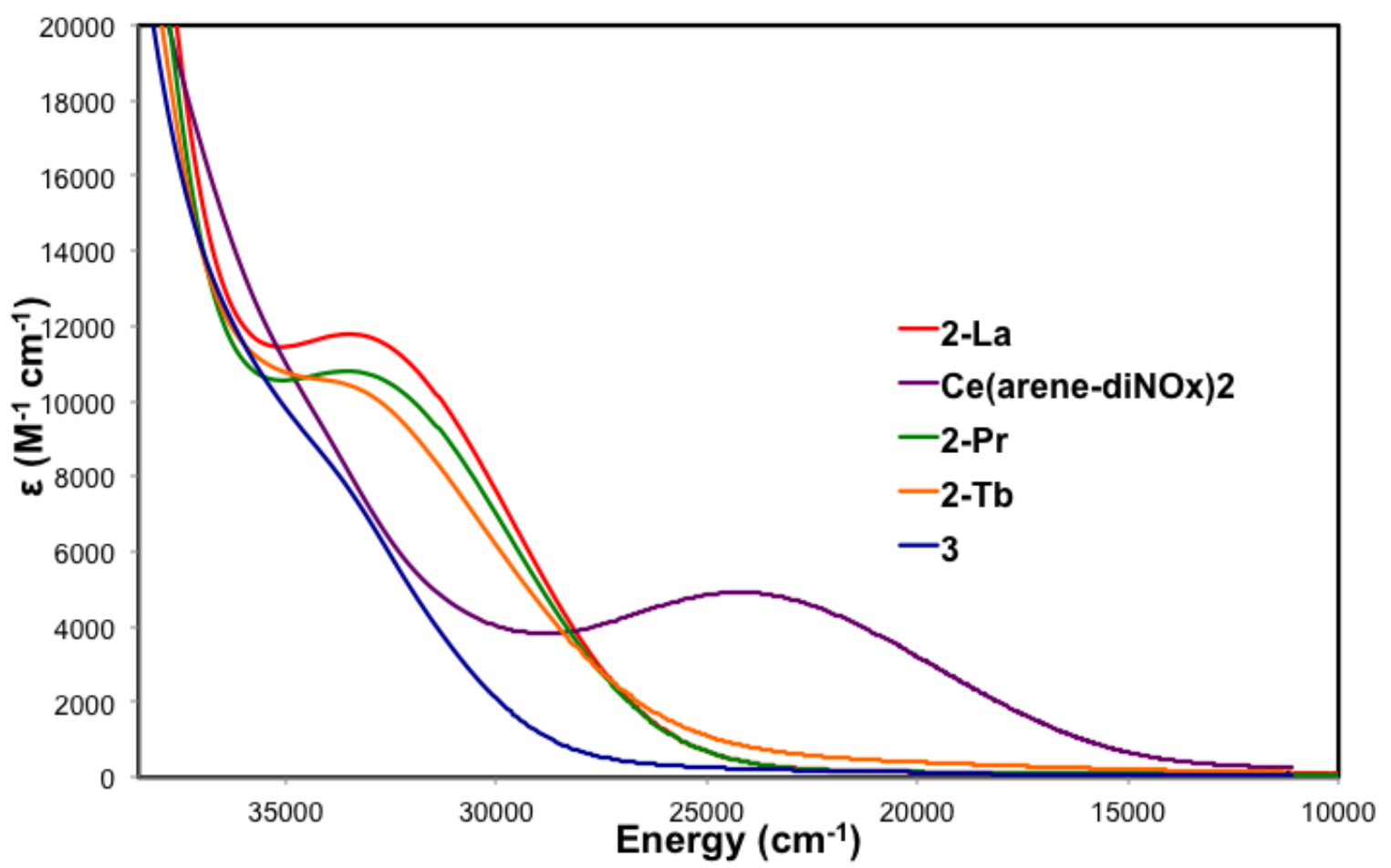

Figure S18. UV-Vis spectrum of Ce(arene-diNOx $)_{2}, \mathbf{2}-\mathbf{L n}(\mathrm{Ln}=\mathrm{La}, \operatorname{Pr}$ and $\mathrm{Tb}), \mathbf{3} \cdot \mathbf{C H}_{\mathbf{2}} \mathbf{C l}_{\mathbf{2}}$ in methylene chloride. 


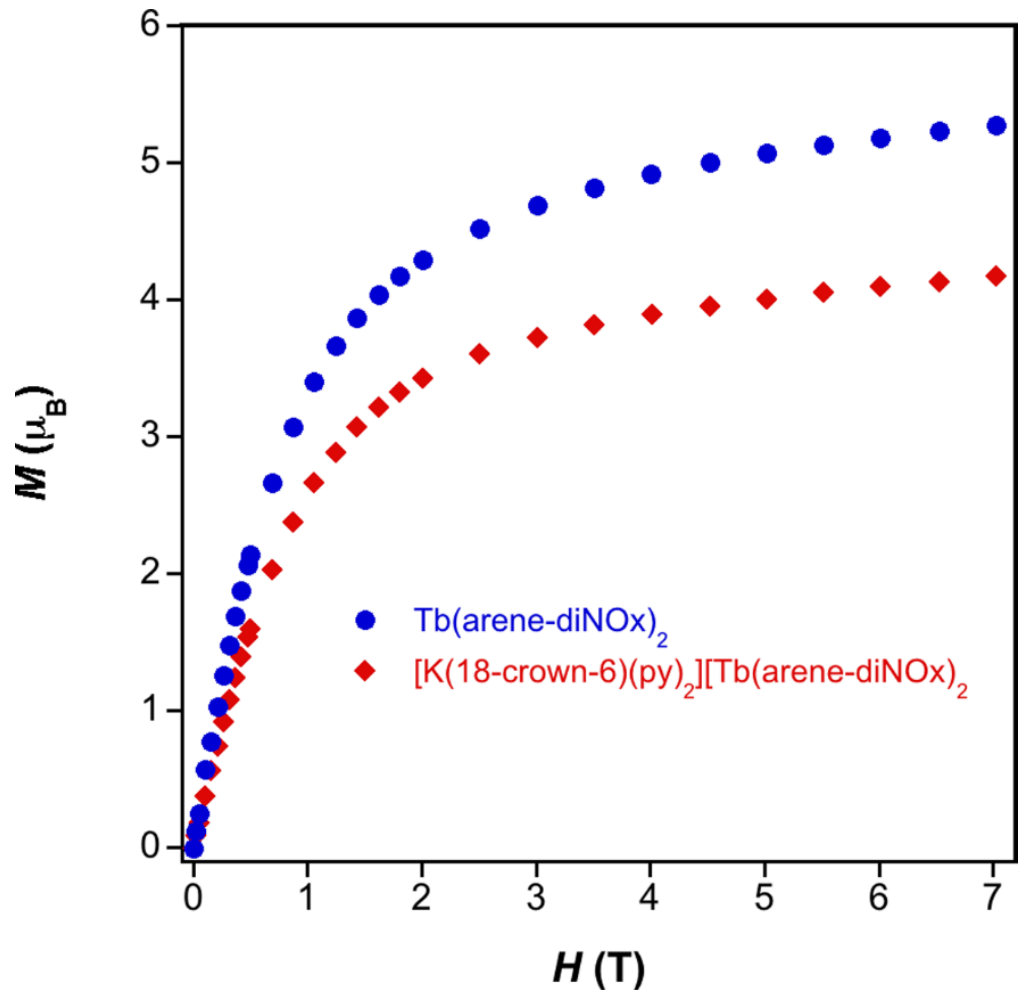

Figure S19. Plot of magnetization versus field. 
Table S1. Summary of structure determination of compound $\mathrm{H}_{3}$ arene-triNOx, 1, 2'-Pr and 2-Pr.

\begin{tabular}{|c|c|c|c|c|}
\hline & $\mathrm{H}_{3}$ arene-triNOx$\cdot 3 \mathrm{THF}$ & 1 & $2^{\prime}-\operatorname{Pr} \cdot 0.5 C_{6} H_{14}$ & $2-\operatorname{Pr} \cdot 0.5 \mathrm{C}_{6} \mathrm{H}_{5} \mathrm{~N}$ \\
\hline Empirical formula & $\mathrm{C}_{48} \mathrm{H}_{69} \mathrm{~N}_{3} \mathrm{O}_{6}$ & $\mathrm{C}_{72} \mathrm{H}_{86} \mathrm{~N}_{6} \mathrm{O}_{6} \mathrm{Ce}$ & $\mathrm{C}_{63} \mathrm{H}_{87} \mathrm{~N}_{4} \mathrm{O}_{8} \mathrm{KPr}$ & $\mathrm{C}_{303} \mathrm{H}_{383} \mathrm{~N}_{23} \mathrm{O}_{40} \mathrm{~K}_{4} \mathrm{Pr}_{4}$ \\
\hline Formula weight & 784.06 & 1271.59 & 1208.38 & 5707.36 \\
\hline Temperature & $100(1) \mathrm{K}$ & $100(1) \mathrm{K}$ & $100(1) \mathrm{K}$ & $100(1) \mathrm{K}$ \\
\hline Wavelength & $0.71073 \AA$ & $0.71073 \AA$ & $0.71073 \AA$ & $0.71073 \AA$ \\
\hline Crystal system & Rhombohedral & Triclinic & Triclinic & Triclinic \\
\hline Space group & $\mathrm{R} \overline{3}$ & $\overline{\mathrm{P}} \overline{1}$ & $\overline{\mathrm{P}} \overline{1}$ & $\overline{\mathrm{P}} \overline{1}$ \\
\hline \multicolumn{5}{|l|}{ Cell constants: } \\
\hline $\mathrm{a}$ & 22.8161(10) $\AA$ & $11.5266(3) \AA$ & $12.7775(5) \AA$ & $12.1223(5) \AA$ \\
\hline $\mathrm{b}$ & - & $17.3016(5) \AA$ & $13.3437(5) \AA$ & $24.8418(10) \AA$ \\
\hline $\mathrm{c}$ & 14.7211(8) $\AA$ & 21.0553(6) $\AA$ & 19.6456(7) $\AA$ & $28.1590(11) \AA$ \\
\hline$\alpha$ & - & $93.074(2)^{\circ}$ & $82.354(2)^{\circ}$ & $65.602(2)^{\circ}$ \\
\hline$\beta$ & - & $93.705(2)^{\circ}$ & $78.333(2)^{\circ}$ & $80.124(2)^{\circ}$ \\
\hline$\gamma$ & - & $98.827(2)^{\circ}$ & $70.190(2)^{\circ}$ & $77.713(2)^{\circ}$ \\
\hline Volume & $6636.7(5) \AA^{3}$ & $4132.0(2) \AA^{3}$ & $3078.7(2) \AA^{3}$ & $7512.3(5) \AA^{3}$ \\
\hline $\mathrm{Z}$ & 6 & 2 & 2 & 1 \\
\hline Density (calculated) & $1.177 \mathrm{Mg} / \mathrm{m}^{3}$ & $1.022 \mathrm{Mg} / \mathrm{m}^{3}$ & $1.304 \mathrm{Mg} / \mathrm{m}^{3}$ & $1.262 \mathrm{Mg} / \mathrm{m}^{3}$ \\
\hline Absorption coefficient & $0.077 \mathrm{~mm}^{-1}$ & $0.595 \mathrm{~mm}^{-1}$ & $0.914 \mathrm{~mm}^{-1}$ & $0.762 \mathrm{~mm}^{-1}$ \\
\hline $\mathrm{F}(000)$ & 2556 & 1332 & 1270 & 2994 \\
\hline Crystal size & $0.20 \times 0.07 \times 0.04 \mathrm{~mm}^{3}$ & $\begin{array}{c}0.46 \times 0.10 \times 0.03 \\
\mathrm{~mm}^{3}\end{array}$ & $0.40 \times 0.25 \times 0.20 \mathrm{~mm}^{3}$ & $0.22 \times 0.08 \times 0.04 \mathrm{~mm}^{3}$ \\
\hline $\begin{array}{l}\text { Theta range for } \\
\text { data collection }\end{array}$ & 1.73 to $27.51^{\circ}$ & 1.59 to $27.51^{\circ}$ & 1.63 to $27.57^{\circ}$ & 1.43 to $27.56^{\circ}$ \\
\hline Index ranges & $\begin{array}{c}-29 \leq \mathrm{h} \leq 29 \\
-29 \leq \mathrm{k} \leq 29 \\
-19 \leq 1 \leq 18\end{array}$ & $\begin{array}{c}-14 \leq \mathrm{h} \leq 14 \\
-22 \leq \mathrm{k} \leq 22 \\
0 \leq 1 \leq 27\end{array}$ & $\begin{array}{l}-16 \leq \mathrm{h} \leq 16 \\
-17 \leq \mathrm{k} \leq 17 \\
-25 \leq 1 \leq 25\end{array}$ & $\begin{array}{c}-15 \leq \mathrm{h} \leq 15 \\
-32 \leq \mathrm{k} \leq 32 \\
-36 \leq 1 \leq 36\end{array}$ \\
\hline Reflections collected & 56138 & 158685 & 100217 & 198417 \\
\hline Independent reflections & $\begin{array}{c}3406 \\
{[\mathrm{R} \text { (int) }=0.0574]}\end{array}$ & $\begin{array}{c}18938 \\
{[\mathrm{R}(\mathrm{int})=0.0518]}\end{array}$ & $\begin{array}{c}14154 \\
{[\mathrm{R}(\mathrm{int})=0.0177]}\end{array}$ & $\begin{array}{c}34571 \\
{[\mathrm{R} \text { (int) }=0.0278]}\end{array}$ \\
\hline $\begin{array}{l}\text { Completeness to } \\
\text { theta }=27.59^{\circ}\end{array}$ & $100.0 \%$ & $99.8 \%$ & $99.3 \%$ & $99.5 \%$ \\
\hline Absorption correction & $\begin{array}{c}\text { Semi-empirical from } \\
\text { equivalents }\end{array}$ & $\begin{array}{c}\text { Semi-empirical from } \\
\text { equivalents }\end{array}$ & $\begin{array}{l}\text { Semi-empirical from } \\
\text { equivalents }\end{array}$ & $\begin{array}{l}\text { Semi-empirical from } \\
\text { equivalents }\end{array}$ \\
\hline Max. and min. transmission & 0.7456 and 0.7021 & 0.7456 and 0.6280 & 0.7456 and 0.6634 & 0.7456 and 0.7118 \\
\hline Refinement method & $\begin{array}{l}\text { Full-matrix least-squares } \\
\text { on } \mathrm{F}^{2}\end{array}$ & $\begin{array}{l}\text { Full-matrix least- } \\
\text { squares on } \mathrm{F}^{2}\end{array}$ & $\begin{array}{l}\text { Full-matrix least- } \\
\text { squares on } \mathrm{F}^{2}\end{array}$ & $\begin{array}{l}\text { Full-matrix least- } \\
\text { squares on } \mathrm{F}^{2}\end{array}$ \\
\hline $\begin{array}{l}\text { Data / restraints / } \\
\text { parameters }\end{array}$ & $3406 / 30 / 177$ & $18938 / 0 / 787$ & $14154 / 112 / 729$ & 34571 / $384 / 1757$ \\
\hline Goodness-of-fit on $\mathrm{F}^{2}$ & 1.012 & 1.060 & 1.110 & 1.061 \\
\hline $\begin{array}{l}\text { Final } \mathrm{R} \text { indices } \\
{[\mathrm{I}>2 \operatorname{sigma}(\mathrm{I})]}\end{array}$ & $\begin{array}{c}\mathrm{R} 1=0.0426, \\
\mathrm{wR} 2=0.0956\end{array}$ & $\begin{array}{c}\mathrm{R} 1=0.0708 \\
\mathrm{wR} 2=0.1783\end{array}$ & $\begin{array}{c}\mathrm{R} 1=0.0353, \\
\mathrm{wR} 2=0.0849\end{array}$ & $\begin{array}{c}\mathrm{R} 1=0.0839, \\
\mathrm{wR} 2=0.2040\end{array}$ \\
\hline $\mathrm{R}$ indices (all data) & $\begin{array}{l}\mathrm{R} 1=0.0621 \\
\mathrm{wR} 2=0.1055\end{array}$ & $\begin{array}{l}\mathrm{R} 1=0.0799 \\
\mathrm{wR} 2=0.1845\end{array}$ & $\begin{array}{c}\mathrm{R} 1=0.0388 \\
\mathrm{wR} 2=0.0881\end{array}$ & $\begin{array}{c}\mathrm{R} 1=0.0919, \\
\mathrm{wR} 2=0.2098\end{array}$ \\
\hline $\begin{array}{l}\text { Largest diff. peak } \\
\quad \text { and hole }\end{array}$ & 0.305 and -0.219 e. $\AA^{-3}$ & $\begin{array}{c}8.530 \text { and }-2.216 \\
\text { e. } \AA^{-{ }^{-3}}\end{array}$ & 2.314 and $-2.625 \mathrm{e} . \AA^{-3}$ & 7.077 and -8.990 e. $\AA^{-3}$ \\
\hline
\end{tabular}


Table S2. Summary of structure determination of compound $\mathbf{2}^{\prime}-\mathbf{T b}, \mathbf{2}-\mathbf{T b}$ and $\mathbf{3}$.

\begin{tabular}{|c|c|c|c|}
\hline & $22^{\prime}-\mathrm{Tb} \cdot 0.5 \mathrm{C}_{6} \mathrm{H}_{14}$ & $2-\mathrm{Tb} \cdot 0.5 \mathrm{C}_{5} \mathrm{H}_{5} \mathrm{~N}$ & $3 \cdot \mathrm{CH}_{2} \mathrm{Cl}_{2}$ \\
\hline Empirical formula & $\mathrm{C}_{126} \mathrm{H}_{174} \mathrm{~N}_{8} \mathrm{O}_{16} \mathrm{~K}_{2} \mathrm{~Tb}_{2}$ & $\mathrm{C}_{301} \mathrm{H}_{381} \mathrm{~N}_{25} \mathrm{O}_{40} \mathrm{~K}_{4} \mathrm{~Tb}_{4}$ & $\mathrm{C}_{53} \mathrm{H}_{62} \mathrm{~N}_{4} \mathrm{O}_{4} \mathrm{Cl}_{2} \mathrm{~Tb}$ \\
\hline Formula weight & 2452.77 & 5781.39 & 1048.89 \\
\hline Temperature & $100(1) \mathrm{K}$ & $100(1) \mathrm{K}$ & $100(1) \mathrm{K}$ \\
\hline Wavelength & $0.71073 \AA$ & $0.71073 \AA$ & $0.71073 \AA$ \\
\hline Crystal system & Triclinic & Triclinic & Monoclinic \\
\hline Space group & $\overline{\mathrm{P}} \overline{1}$ & $\overline{\mathrm{P}} \overline{1}$ & $\mathrm{P} 2{ }_{1} / \mathrm{n}$ \\
\hline \multicolumn{4}{|l|}{ Cell constants: } \\
\hline $\mathrm{a}$ & $12.804(2) \AA$ & $12.0432(4) \AA$ & $11.4328(4) \AA$ \\
\hline $\mathrm{b}$ & $13.000(2) \AA$ & $24.8248(10) \AA$ & $18.0611(6) \AA$ \\
\hline $\mathrm{c}$ & $38.505(6) \AA$ & $28.1632(11) \AA$ & $23.3466(9) \AA$ \\
\hline$\alpha$ & $92.574(9)^{\circ}$ & $65.892(2)^{\circ}$ & - \\
\hline$\beta$ & $95.787(9)^{\circ}$ & $79.805(2)^{\circ}$ & $92.092(2)^{\circ}$ \\
\hline$\gamma$ & $106.729(9)^{\circ}$ & $77.654(2)^{\circ}$ & - \\
\hline Volume & $6088.3(16) \AA^{3}$ & $7469.8(5) \AA^{3}$ & $4817.6(3) \AA^{3}$ \\
\hline $\mathrm{Z}$ & 2 & 1 & 4 \\
\hline Density (calculated) & $1.338 \mathrm{Mg} / \mathrm{m}^{3}$ & $1.285 \mathrm{Mg} / \mathrm{m}^{3}$ & $1.446 \mathrm{Mg} / \mathrm{m}^{3}$ \\
\hline Absorption coefficient & $1.286 \mathrm{~mm}^{-1}$ & $1.061 \mathrm{~mm}^{-1}$ & $1.628 \mathrm{~mm}^{-1}$ \\
\hline $\mathrm{F}(000)$ & 2564 & 3018 & 2156 \\
\hline Crystal size & $0.40 \times 0.10 \times 0.07 \mathrm{~mm}^{3}$ & $0.10 \times 0.08 \times 0.07 \mathrm{~mm}^{3}$ & $0.25 \times 0.25 \times 0.10 \mathrm{~mm}^{3}$ \\
\hline $\begin{array}{l}\text { Theta range for } \\
\text { data collection }\end{array}$ & 1.07 to $27.65^{\circ}$ & 1.42 to $27.60^{\circ}$ & 1.43 to $27.56^{\circ}$ \\
\hline Index ranges & $\begin{array}{c}-16 \leq \mathrm{h} \leq 16 \\
-16 \leq \mathrm{k} \leq 16 \\
-50 \leq 1 \leq 49\end{array}$ & $\begin{array}{c}-15 \leq \mathrm{h} \leq 15 \\
-32 \leq \mathrm{k} \leq 32 \\
-36 \leq 1 \leq 36\end{array}$ & $\begin{array}{c}-14 \leq \mathrm{h} \leq 14 \\
-23 \leq \mathrm{k} \leq 23 \\
-30 \leq 1 \leq 30\end{array}$ \\
\hline Reflections collected & 146554 & 258721 & 82476 \\
\hline Independent reflections & $\begin{array}{c}27999 \\
{[\mathrm{R} \text { (int) }=0.0777]}\end{array}$ & $\begin{array}{c}34377 \\
{[\mathrm{R} \text { (int) }=0.0476]}\end{array}$ & $\begin{array}{c}11096 \\
{[\mathrm{R}(\mathrm{int})=0.0858]}\end{array}$ \\
\hline $\begin{array}{l}\text { Completeness to } \\
\text { theta }=27.59^{\circ}\end{array}$ & $98.7 \%$ & $99.1 \%$ & $99.8 \%$ \\
\hline Absorption correction & $\begin{array}{c}\text { Semi-empirical from } \\
\text { equivalents }\end{array}$ & $\begin{array}{c}\text { Semi-empirical from } \\
\text { equivalents }\end{array}$ & $\begin{array}{c}\text { Semi-empirical from } \\
\text { equivalents }\end{array}$ \\
\hline Max. and min. transmission & 0.7456 and 0.5511 & 0.7456 and 0.6738 & 0.7456 and 0.6451 \\
\hline Refinement method & $\begin{array}{l}\text { Full-matrix least-squares on } \\
\qquad \mathrm{F}^{2}\end{array}$ & $\begin{array}{l}\text { Full-matrix least-squares on } \\
\qquad \mathrm{F}^{2}\end{array}$ & $\begin{array}{l}\text { Full-matrix least-squares on } \\
\qquad \mathrm{F}^{2}\end{array}$ \\
\hline Data / restraints / parameters & 27999 / 477 / 1376 & 34377 / 459 / 1766 & $11096 / 0 / 590$ \\
\hline Goodness-of-fit on $\mathrm{F}^{2}$ & 1.207 & 1.0641 & 1.135 \\
\hline Final $R$ indices $[I>2 \operatorname{sigma}(I)]$ & $\begin{array}{c}\mathrm{R} 1=0.1713, \\
\mathrm{wR} 2=0.4040\end{array}$ & $\begin{array}{c}\mathrm{R} 1=0.0485 \\
\mathrm{wR} 2=0.1354\end{array}$ & $\begin{array}{c}\mathrm{R} 1=0.0656 \\
\mathrm{wR} 2=0.1483\end{array}$ \\
\hline $\mathrm{R}$ indices (all data) & $\begin{array}{l}\mathrm{R} 1=0.1981, \\
\mathrm{wR} 2=0.4214\end{array}$ & $\begin{array}{l}\mathrm{R} 1=0.0634, \\
\mathrm{wR} 2=0.1459\end{array}$ & $\begin{array}{c}\mathrm{R} 1=0.0978 \\
\mathrm{wR} 2=0.1635\end{array}$ \\
\hline $\begin{array}{l}\text { Largest diff. peak } \\
\text { and hole }\end{array}$ & 12.691 and -4.959 e. $\AA^{-3}$ & 2.684 and $-1.613 \mathrm{e} . \AA^{-3}$ & 5.753 and -1.661 e. $\AA^{-3}$ \\
\hline
\end{tabular}

